\title{
Efficient Transamidation of Primary Carboxamides by in Situ Activation with $N, N-$ Dialkylformamide Dimethyl Acetals
}

Thomas A. Dineen, Matthew A. Zajac, Andrew G. Myers*

\section{Supporting Information}

Index:

General Experimental Procedures

Materials

Instrumentation

Preparation of $N, N$-Diisopropylfomamide Dimethyl Acetal

Preparation of $N$ '-Acyl $N, N$-Diisopropylformamidines

Transamidation of $N$ '-Acyl $N, N$-Diisopropylformamidines using Scandium Triflate as Catalyst

Preparation of a 0.7 M Solution of Zirconium Chloride in Acetonitrile

Transamidation using $N, N$-Diisopropylformamide Dimethyl Acetal as Activator and Zirconium

Chloride as Promoter

Transamidation using $N, N$-Dimethylformamide Dimethyl Acetal as Activator and Zirconium

General Experimental Procedures: All reactions were performed in flame-dried glassware fitted with rubber septa under a positive pressure of argon, unless otherwise noted. Air- and moisture-sensitive liquids were transferred via syringe or stainless steel cannula. Organic solutions were concentrated by rotary evaporation below $35{ }^{\circ} \mathrm{C}$ at $40 \mathrm{mmHg}$. Analytical and preparative thin-layer chromatography (TLC) was performed using glass plates pre-coated with a 0.25 -mm layer of silica gel impregnated with a fluorescent indicator $(254 \mathrm{~nm})$. TLC plates were visualized by exposure to ultraviolet light and/or submersion in aqueous ceric ammonium molybdate solution (CAM) or solutions of ninhydrin in $n$-butanol, followed by 
brief heating on a hot plate $\left(215^{\circ} \mathrm{C}, 10-15 \mathrm{~s}\right)$. Flash-column chromatography was performed as described by Still et al., ${ }^{1}$ employing silica gel (60 $\AA$, standard grade) purchased from Sorbent Technologies.

Materials: Commercial solvents and reagents were used as received with the following exceptions. Dichloromethane and ether were purified by the method of Pangborn et al. ${ }^{2}$ Benzylamine, pyrrolidine, $\mathrm{N}$ benzylmethylamine, and s-butylamine were distilled from calcium hydride at $760 \mathrm{mmHg}$ under an atmosphere of argon and the distilled solution was stored under argon. Free-base forms of $\alpha$-amino ester substrates were prepared from commercial hydrochloride salts by dissolution of the latter in a solution of aqueous sodium carbonate, extraction of the aqueous solution with ether, drying of the ethereal solutions over anhydrous sodium sulfate, and concentration of the dried solutions to provide the free-base form of the amino acid. 5-A Molecular sieves were activated by washing the commercial pellets with dichloromethane, crushing the washed sieves in a mortar and pestle, and heating the resulting powder at $170{ }^{\circ} \mathrm{C}$ under vacuum ( $0.1 \mathrm{mmHg})$ for $24 \mathrm{~h}$. The crushed, activated sieves were stored in an oven at $150{ }^{\circ} \mathrm{C}$ until needed.

Instrumentation: Proton nuclear magnetic resonance spectra $\left({ }^{1} \mathrm{H}\right.$ NMR) were recorded on Varian Mercury $400(400 \mathrm{MHz})$ or Varian INOVA $500(500 \mathrm{Mhz})$ at $23^{\circ} \mathrm{C}$. Chemical shifts are expressed in parts per million (ppm, $\delta$ scale) downfield from tetramethylsilane and are referenced to residual protium in the NMR solvent $\left(\mathrm{CHCl}_{3}, \delta\right.$ 7.26). Data are represented as follows: chemical shift, multiplicity $(\mathrm{s}=$ singlet, $\mathrm{d}=$ doublet, $\mathrm{t}$ = triplet, $\mathrm{sep}=$ septet, $\mathrm{m}$ = multiplet and/or multiple resonances, $\mathrm{br}=$ broad), coupling constant in Hertz, integration and assignment. Carbon nuclear magnetic resonance spectra $\left({ }^{13} \mathrm{C} N M R\right)$ were recorded on a Varian Mercury $400(100 \mathrm{MHz})$ at $23^{\circ} \mathrm{C}$. Chemical shifts are reported in parts per million downfield from tetramethylsilane and are referenced to the carbon resonances of the solvent $\left(\mathrm{CDCl}_{3}, \delta 77.0\right)$. Samples prepared infrared (IR) spectroscopy were prepared as neat films by evaporation of dichloromethane solutions; infrared spectra were recorded using a Perkin-Elmer FT-IR spectrometer referenced to a polystyrene standard. Data are represented as follows: frequency of absorption $\left(\mathrm{cm}^{-1}\right)$, intensity of absorption (vs = very strong, $\mathrm{s}=$ strong, $\mathrm{m}=$ medium, $\mathrm{w}=$ weak, $\mathrm{br}=$ broad). High-resolution mass spectra were obtained at the Harvard University Mass Spectrometry Facility.

${ }^{1}$ Still, W. C.; Kahn, M.; Mitra, A. J. Org. Chem. 1978, 43, 2923.

${ }^{2}$ Pangborn, A. B.; Giardello, M. A.; Grubbs, R. H.; Rosen, R. K.; Timmers, F. J. Organometallics 1996, 15, 1518. 


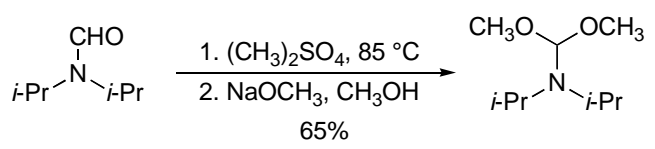

$N, N$-Diisopropylformamide dimethyl acetal (DIF-DMA). The following is a slight modification of the procedure of Bredereck et al. ${ }^{3} \mathrm{~N}, \mathrm{~N}$-Diisopropylformamide (Aldrich Co., $28.1 \mathrm{~mL}, 25.0 \mathrm{~g}, 193 \mathrm{mmol}$ ) and dimethyl sulfate (Aldrich Co., $18.8 \mathrm{~mL}, 25.0$ g, $199 \mathrm{mmol}$ ) were combined in a 250-mL, round-bottom flask fitted with a Teflon-coated stir-bar. The resulting clear, yellow solution was heated at $85{ }^{\circ} \mathrm{C}$, with stirring, for $4 \mathrm{~d}$. The resulting brown reaction mixture was then cooled to $23^{\circ} \mathrm{C}$, ether $(20 \mathrm{~mL})$ was added to the cooled solution, and the resulting biphasic mixture was stirred vigorously for 5 min. The upper, ethereal layer was removed with a cannula (18-ga), and an additional portion of ether (20 mL) was added to the residue. The upper, ethereal layer was removed with a cannula (18-ga). The remaining thick, brown mixture was poured into a solution of sodium methoxide in methanol (prepared by the addition of $10.0 \mathrm{~g}$ (435 mmol) of sodium metal to $100 \mathrm{~mL}$ dry methanol) in a 250-mL, round-bottom flask fitted with a Teflon-coated stir bar. The resulting brown mixture was stirred for $14 \mathrm{~h}$ at $23^{\circ} \mathrm{C}$, then was extracted with hexane $(5 \times 100 \mathrm{~mL})$. The hexane extracts were combined, and the combined solution was dried over anhydrous sodium sulfate. The dried solution was concentrated to afford a clear, colorless liquid containing a white, suspended precipitate. The mixture was distilled (bath $105^{\circ} \mathrm{C}$ ) to give $22 \mathrm{~g}$ of DIF-DMA as a clear, colorless liquid $\left(65 \%, 88-89{ }^{\circ} \mathrm{C}, 40 \mathrm{mmHg}\right)$, contaminated with $\sim 3 \% N, N$-diisopropylformamide: ${ }^{1} \mathrm{H}$ NMR (400 MHz, $\left.\mathrm{CDCl}_{3}\right), \delta 4.61\left(\mathrm{~s}, 1 \mathrm{H},\left(\mathrm{CH}_{3} \mathrm{O}\right)_{2} \mathrm{CHN}\right), 3.34$ (sep, J = $\left.7.0 \mathrm{~Hz}, 2 \mathrm{H}, \mathrm{NCH}\left(\mathrm{CH}_{3}\right)_{2}\right), 3.25(\mathrm{~s}$, $\left.6 \mathrm{H}, \mathrm{OCH}_{3}\right), 1.06$ (d, J = 7.0 Hz, $\left.12 \mathrm{H}, \mathrm{CH}\left(\mathrm{CH}_{3}\right)_{2}\right)$.

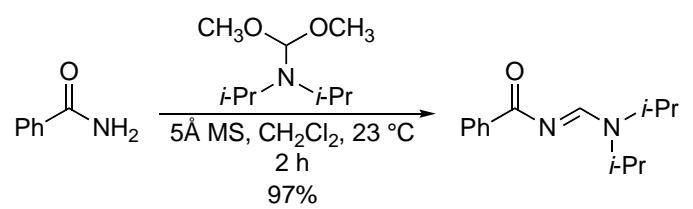

Preparation of $\quad N^{\prime}$-Benzoyl $N, N$-Diisopropylformamidine from Benzamide and $N, N$ Diisopropylformamide Dimethyl Acetal. A 50-mL round-bottom flask containing a Teflon-coated stir bar and crushed 5-A MS (2.5 g) was evacuated (0.1 mmHg), and a good flame was applied for 2 min to dry

\footnotetext{
${ }^{3}$ Bredereck, H.; Simchem, G.; Rebsdat, S.; Kantlehn, W.; Horn, P.; Wahl, R.; Hoffmann, H.; Grieshab, P. Chem. Ber. 1968, 101, 41.
} 
the molecular sieves. The flame was removed, the flask was allowed to cool to $23{ }^{\circ} \mathrm{C}$, and an argon atmosphere was introduced. Benzamide (300 mg, $2.48 \mathrm{mmol}$ ) and dichloromethane (25 mL) were added in sequence. The resulting suspension was stirred for 5 min at $23^{\circ} \mathrm{C}$, and $N, N$-diisopropylformamide dimethyl acetal (DIF-DMA, $530 \mu \mathrm{L}, 2.97 \mathrm{mmol}, 1.25$ equiv) was added via syringe. After stirring for $3 \mathrm{~h}$ at $23^{\circ} \mathrm{C}$, the reaction mixture was filtered through Celite, and the filter cake was washed with dichloromethane $(3 \times$ $10 \mathrm{~mL}$ ). The filtrates were combined, and the combined solution was evaporated. The residue was purified by flash-column chromatography on silica gel (50\% ether-hexane) providing $558 \mathrm{mg}$ of $N$ '-benzoyl $N, N$ diisopropylformamidine as a white, amorphous solid (97\%): ${ }^{1} \mathrm{H}$ NMR (400 MHz, $\left.\mathrm{CDCl}_{3}\right) \delta 8.83(\mathrm{~s}, 1 \mathrm{H}$, NCHN), 8.30-8.25 (m, 2 H, Ar-H), 7.46-7.51 (m, 1 H, Ar-H), 7.45-7.39 (m, 2 H, Ar-H), 4.82 (sep, J = 6.8 $\mathrm{Hz}, 1 \mathrm{H}$, isopropyl $\left.\mathrm{CH}\left(\mathrm{CH}_{3}\right)_{2}\right)$, 3.75 (sep, $\mathrm{J}=6.8 \mathrm{~Hz}, 1 \mathrm{H}$, isopropyl $\left.\mathrm{CH}\left(\mathrm{CH}_{3}\right)_{2}\right), 1.38(\mathrm{~d}, \mathrm{~J}=6.8 \mathrm{~Hz}, 6 \mathrm{H}$, isopropyl $\left.\mathrm{CH}\left(\mathrm{CH}_{3}\right)_{2}\right), 1.37$ (d, J = 6.8 Hz, $\left.6 \mathrm{H}, \mathrm{CH}\left(\mathrm{CH}_{3}\right)_{2}\right) ;{ }^{13} \mathrm{C}$ NMR (100 MHz, $\left.\mathrm{CDCl}_{3}\right), \delta$ 177.4, 157.9, 137.0, 131.4, 129.5, 127.6, 48.7, 47.5, 23.3, 19.6; FTIR (neat) 3066 (vw), 2975 (m), 2937 (w), 1640 (s), 1582 (s), 1561 (vs), 1499 (s) cm ${ }^{-1}$; HRMS-ES (m/z): [M + H] $]^{+}$calcd. for $\mathrm{C}_{14} \mathrm{H}_{21} \mathrm{~N}_{2} \mathrm{O}$ 233.1654; found 233.1655.

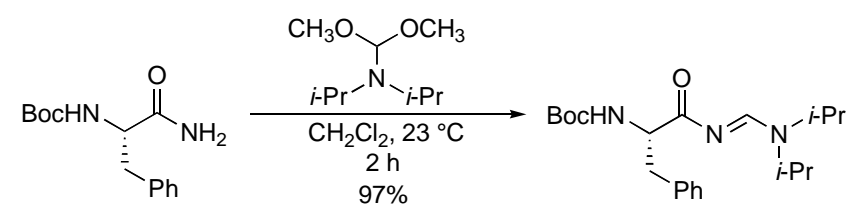

Preparation of $N^{\prime}$-( $N^{\alpha}$-(tert-Butoxycarbonyl)-L-phenylalaninyl) $N, N$-Diisopropylformamidine from $N^{\alpha}$-(tert-Butoxycarbonyl)-L-phenylalaninamide and $N, N$-Diisopropylformamidine Dimethyl Acetal. $N, N$-diisopropylformamide dimethyl acetal (DIF-DMA, $140 \mu \mathrm{L}, 1.40 \mathrm{mmol}, 1.5$ equiv) was added to a stirring solution of $\quad N^{\alpha}$-(tert-Butoxycarbonyl)-L-phenylalaninamide $\quad\left(\begin{array}{lllll}120 & \mathrm{mg}, & 0.45 \mathrm{mmol}\end{array}\right)$ in dichloromethane $(2.5 \mathrm{~mL})$ at $23^{\circ} \mathrm{C}$. After stirring for $2 \mathrm{~h}$ at $23^{\circ} \mathrm{C}$, the reaction mixture was filtered through Celite, and the filter cake was washed with dichloromethane $(3 \times 10 \mathrm{~mL})$. The filtrates were combined, and the combined solution was evaporated. The residue was purified by flash-column chromatography on silica gel (80\% ether-hexane) to give $161.2 \mathrm{mg}$ of $N^{\prime}$-( $N^{\alpha}$-(tert-butoxycarbonyl)-L-phenylalaninyl) $N, N$ diisopropylformamidine as a white solid (95\%): ${ }^{1} \mathrm{H}$ NMR (500 MHz, $\left.\mathrm{C}_{6} \mathrm{D}_{6}\right) \delta 8.52$ (s, $1 \mathrm{H}, \mathrm{NCHN}$ ), 7.34- 
7.23 (m, 2 H, Ar-H), 7.16-6.80 (m, 3 H, Ar-H), 5.84 (d, 1 H, J = 7.0 Hz, CONHCH $)_{2}$, 5.08 (dt, 1 H, J = 7.0, $5.5 \mathrm{~Hz}$, NHCHCO), 4.17 (sep, $1 \mathrm{H}, \mathrm{J}=6.8 \mathrm{~Hz}$, isopropyl $\left.\mathrm{CH}\left(\mathrm{CH}_{3}\right)_{2}\right), 3.50(\mathrm{ABq}[\mathrm{J}=13.2 \mathrm{~Hz}]$ of d [J= 5.5 $\mathrm{Hz}$ ], 2H, CHCH $2 \mathrm{Ph}$ ), $2.73\left(\right.$ sep, $1 \mathrm{H}, \mathrm{J}=6.8 \mathrm{~Hz}$, isopropyl $\left.\mathrm{CH}\left(\mathrm{CH}_{3}\right)_{2}\right), 1.43(\mathrm{~s}, 10 \mathrm{H}$, tert-butoxy OC $\left.\left(\mathrm{CH}_{3}\right)_{3}\right)$, 0.84-0.79 (m, $6 \mathrm{H}$, isopropyl $\left.\mathrm{CH}\left(\mathrm{CH}_{3}\right)_{2}\right)$, 0.60-0.54 (m, $6 \mathrm{H}$, isopropyl $\left.\mathrm{CH}\left(\mathrm{CH}_{3}\right)_{2}\right)$.

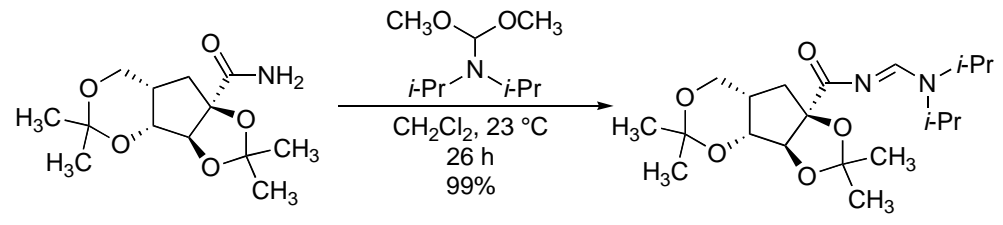

Preparation of $N^{\prime}$-(2,3:4,6-O-Isopropylidene-2-keto-gulonanyl) $N, N$-Diisopropylformamidine from 2,3:4,6-O-Isopropylidene-2-keto-gulonamide and $N, N$-Diisopropylformamide Dimethyl Acetal. $N, N$ diisopropylformamide dimethyl acetal (DIF-DMA, $320 \mu \mathrm{L}, 1.60 \mathrm{mmol}, 2.0$ equiv) was added to a stirring solution of 2,3:4,6-O-isopropylidene-2-keto-gulonamide (218 mg, $0.80 \mathrm{mmol})$ in dichloromethane $(2.0 \mathrm{~mL})$ at $23^{\circ} \mathrm{C}$. After stirring for $26 \mathrm{~h}$ at $23^{\circ} \mathrm{C}$, the reaction mixture was filtered through Celite, and the filter cake was washed with dichloromethane $(3 \times 10 \mathrm{~mL})$. The filtrates were combined, and the combined solution was evaporated. The residue was purified by flash-column chromatography on silica gel (50\% ether-ethyl acetate) to give $305 \mathrm{mg}$ of $N^{\prime}$-(2,3:4,6-O-isopropylidene-2-keto-gulonanyl) $N, N$-diisopropylformamidine as a clear, colorless oil (99\%): ${ }^{1} \mathrm{H}$ NMR (400 MHz, $\left.\mathrm{CDCl}_{3}\right) \delta 8.68$ (s, $\left.1 \mathrm{H}, \mathrm{NCHN}\right), 5.02(\mathrm{~s}, 1 \mathrm{H}, \mathrm{OCHCH})$, 4.80 (sep, 1 H, J = $6.8 \mathrm{~Hz}$, isopropyl $\left.\mathrm{CH}\left(\mathrm{CH}_{3}\right)_{2}\right), 4.27$ (d, $1 \mathrm{H}, \mathrm{J}=2.4 \mathrm{~Hz}$ OCHCH), 4.18 (q, $1 \mathrm{H}, \mathrm{J}=2.4$ Hz, ), 4.15-4.04 (m, $2 \mathrm{H}, \mathrm{OCH}_{2} \mathrm{CH}$ ), 3.69 (sep, $1 \mathrm{H}, \mathrm{J}=6.8 \mathrm{~Hz}$, isopropyl $\left.\mathrm{CH}\left(\mathrm{CH}_{3}\right)_{2}\right), 1.52\left(\mathrm{~s}, 3 \mathrm{H}, \mathrm{O}_{2^{-}}\right.$ $\left.\mathrm{CCH}_{3}\right), 1.42$ (s, $\left.6 \mathrm{H}, \mathrm{O}_{2} \mathrm{C}\left(\mathrm{CH}_{3}\right)_{2}\right), 1.33\left(\mathrm{~s}, 3 \mathrm{H}, \mathrm{O}_{2} \mathrm{CCH}_{3}\right), 1.33$ (d, $6 \mathrm{H}, \mathrm{J}=6.8 \mathrm{~Hz}$, isopropyl CH(CH$\left.)_{2}\right)$, $1.26\left(\mathrm{~d}, 6 \mathrm{H}, \mathrm{J}=6.8 \mathrm{~Hz}\right.$, isopropyl $\left.\mathrm{CH}\left(\mathrm{CH}_{3}\right)_{2}\right)$.

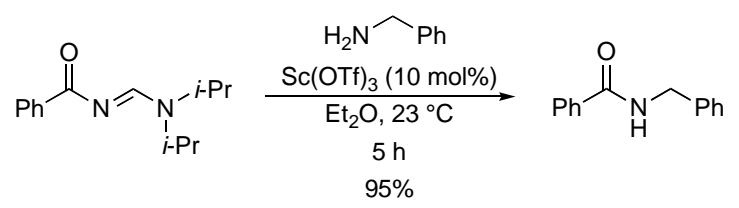

Transamidation of $N$ '-Benzoyl $N, N$-Diisopropylformamidine with Benzylamine to form $N$-Benzyl Benzamide using Scandium Triflate as Catalyst. Scandium triflate (25 mg, $0.05 \mathrm{mmol}, 0.1$ equiv) was added to a stirring solution of benzylamine (164 $\mu \mathrm{L}, 1.50 \mathrm{mmol}, 3$ equiv) and $N^{\prime}$-benzoyl $N, N$ - 
diisopropylformamidine $(116 \mathrm{mg}, 0.500 \mathrm{mmol})$ in ether $(2.5 \mathrm{~mL})$ at $23^{\circ} \mathrm{C}$. The mixture was stirred for $5 \mathrm{~h}$ at $23{ }^{\circ} \mathrm{C}$, then was poured into $0.1 \mathrm{~N}$ aqueous sulfuric acid solution $(10 \mathrm{~mL})$. The aqueous layer was separated and extracted with two 5-mL portions of ether, and the ethereal layers were combined. The combined layers were washed with saturated aqueous sodium chloride solution $(10 \mathrm{~mL})$, the washed solution was dried over anhydrous magnesium sulfate, and the dried solution was concentrated. The residue was purified by flash column chromatography on silica gel (60\% ether-hexane) to afford $84.1 \mathrm{mg}$ of $\mathrm{N}$ benzyl benzamide as a white solid (95\% yield, 92\% over two steps).

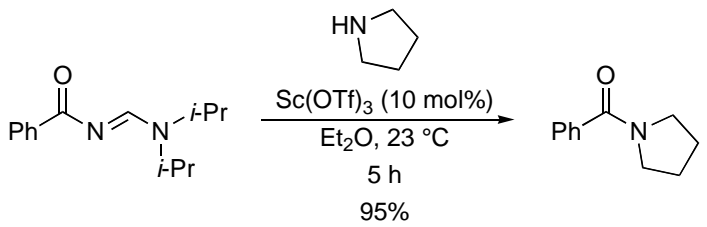

Transamidation of $N$ '-Benzoyl $N, N$-Diisopropylformamidine with Pyrrolidine to form $N$-Benzoyl Pyrrolidine using Scandium Triflate as Catalyst. Scandium triflate ( $25 \mathrm{mg}, 0.05 \mathrm{mmol}, 0.1$ equiv) was added to a stirring solution of pyrrolidine $\left(130 \mu \mathrm{L}, 1.50 \mathrm{mmol}, 3\right.$ equiv) and $N^{\prime}$-benzoyl $N, N$ diisopropylformamidine (116 $\mathrm{mg}, 0.500 \mathrm{mmol})$ in ether $(2.5 \mathrm{~mL})$ at $23^{\circ} \mathrm{C}$. The mixture was stirred for $5 \mathrm{~h}$ at $23{ }^{\circ} \mathrm{C}$, then was poured into $0.1 \mathrm{~N}$ aqueous sulfuric acid solution $(10 \mathrm{~mL})$. The aqueous layer was separated and extracted with two 5-mL portions of ether, and the ethereal layers were combined. The combined layers were washed with saturated aqueous sodium chloride solution $(10 \mathrm{~mL})$, the washed solution was dried over anhydrous magnesium sulfate, and the dried solution was concentrated. The residue was purified by flash column chromatography on silica gel eluting with ether-hexane ( $25 \rightarrow 100 \%)$ to afford $83.4 \mathrm{mg}$ of $N$-benzoylpyrrolidine ${ }^{4}$ as a clear, colorless oil (95\% yield, 92\% over two steps): ${ }^{1} \mathrm{H}$ NMR (500 MHz, CDCl $), \delta$ 7.53-7.51 (m, 2 H, Ar-H), 7.42-7.37 (m, 3 H, Ar-H), 3.66 (t, J = 7.0 Hz, 2 H, $\mathrm{CONCH}_{2}$ ), 3.43 (t, J = 6.5 Hz, $2 \mathrm{H}, \mathrm{CONCH}_{2}$ ), 1.97 (p, J = 7.0 Hz, $2 \mathrm{H}, \mathrm{NCH}_{2} \mathrm{CH}_{2}$ ), 1.88 (p, J = 7.0 Hz, 2 $\mathrm{H}, \mathrm{NCH}_{2} \mathrm{CH}_{2}$ ).

\footnotetext{
${ }^{4}$ Alonso, E.; Ramón, D. J.; Yus, M. Tetrahedron 1998, 54, 13629.
} 


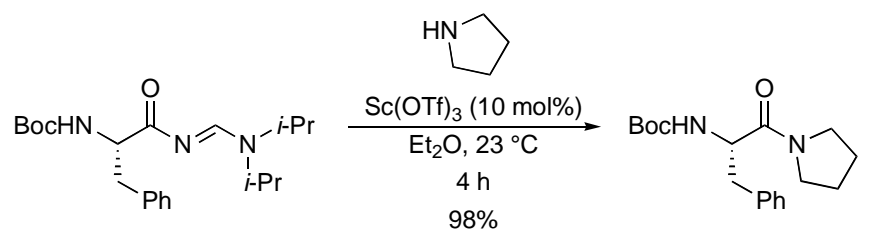

Transamidation of $N^{\prime}$-(N $N^{\alpha}$-(tert-Butoxycarbonyl)-L-phenylalaninyl) $N, N$-Diisopropylformamidine with Pyrrolidine using Scandium Triflate as Catalyst. Scandium triflate (14.9 mg, $0.03 \mathrm{mmol}, 0.1$ equiv) was added to a stirring solution of pyrrolidine (62 $\mu \mathrm{L}, 0.75 \mathrm{mmol}, 2.5$ equiv) and $N^{\prime}$-( $N^{\alpha}$-(tertbutoxycarbonyl)-L-phenylalaninyl) $N, N$-diisopropylformamidine (112 $\mathrm{mg}, 0.30 \mathrm{mmol}$ ) in ether (1.5 mL) at $23^{\circ} \mathrm{C}$. The mixture was stirred for $5 \mathrm{~h}$ at $23^{\circ} \mathrm{C}$, then was poured into $0.1 \mathrm{~N}$ aqueous sulfuric acid solution $(10 \mathrm{~mL})$. The aqueous layer was separated and extracted with two 5-mL portions of ether, and the ethereal layers were combined. The combined layers were washed with saturated aqueous sodium chloride solution $(10 \mathrm{~mL})$, the washed solution was dried over anhydrous magnesium sulfate, and the dried solution was concentrated. The residue was purified by flash column chromatography on silica gel (35\% ethyl acetatehexane) to afford $94.0 \mathrm{mg}$ of $N^{\alpha}$-(tert-butoxycarbonyl)-L-phenylalanine- $N$-pyrrolidinamide ${ }^{5}$ as a clear, colorless oil (98\%): ${ }^{1} \mathrm{H}$ NMR (500 MHz, $\mathrm{C}_{6} \mathrm{D}_{6}$ ) $\delta$ 7.28-7.20 (m, $\left.5 \mathrm{H}, \mathrm{Ar}-\mathrm{H}\right), 5.40$ (d, $1 \mathrm{H}, \mathrm{J}=8.0 \mathrm{~Hz}$, $\mathrm{CONHCH}_{2}$ ), 4.59 (dd, $1 \mathrm{H}, \mathrm{J}=14.8,8.0 \mathrm{~Hz}, \mathrm{NHCHCO}$ ), 3.45-3.28 (m, $3 \mathrm{H}$, pyrrolidinyl $\mathrm{NCH}_{2}$ ), 3.02-2.92 (m, $2 \mathrm{H}, \mathrm{CHCH}_{2} \mathrm{Ph}$ ), 2.57-2.53 (m, 1 H, pyrrolidinyl NCH), 1.76-1.53 (m, 4 H, pyrrolidinyl $\mathrm{NCH}_{2} \mathrm{CH}_{2}$ ), $1.42\left(\mathrm{~s}, 10 \mathrm{H}\right.$, tert-butoxy $\left.\mathrm{OC}\left(\mathrm{CH}_{3}\right)_{3}\right)$.

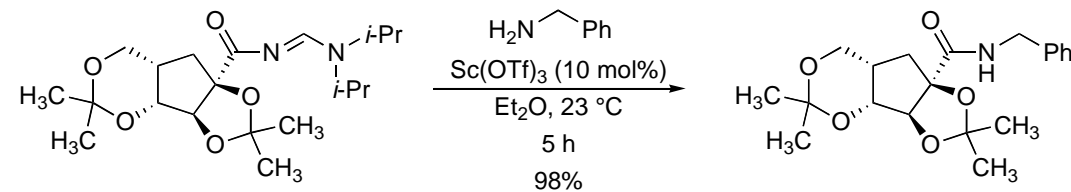

Transamidation of $N^{\prime}$-(2,3:4,6-O-Isopropylidene-2-keto-gulonanyl) $N, N$-Diisopropylformamidine with Benzylamine to form 2,3:4,6-O-Isopropylidene-2-keto- $N$-benzyl-L-gulonamide using Scandium Triflate as Catalyst. Scandium triflate $(11.0 \mathrm{mg}, 0.022 \mathrm{mmol}, 0.1$ equiv) was added to a stirring solution of benzylamine (60 $\mu \mathrm{L}, 0.55 \mathrm{mmol}, 2.5$ equiv) and $N^{\prime}$-(2,3:4,6-O-isopropylidene-2-keto-gulonanyl) $N, N$ diisopropylformamidine ( $85 \mathrm{mg}, 0.22 \mathrm{mmol})$ in ether $(1.1 \mathrm{~mL})$ at $23^{\circ} \mathrm{C}$. The mixture was stirred for $5 \mathrm{~h}$ at $23^{\circ} \mathrm{C}$, then was poured into $0.1 \mathrm{~N}$ aqueous sulfuric acid solution $(10 \mathrm{~mL})$. The aqueous layer was separated

5 Richmond, M. L.; Sprout, C. M.; Seto, C. T. J. Org. Chem. 2005, 70, 8835. 
and extracted with two 5-mL portions of ether, and the ethereal layers were combined. The combined layers were washed with saturated aqueous sodium chloride solution $(10 \mathrm{~mL})$, the washed solution was dried over anhydrous magnesium sulfate, and the dried solution was concentrated. The residue was purified by flash column chromatography on silica gel (60\% ether-hexane) to afford $78.1 \mathrm{mg}$ of 2,3:4,6-Oisopropylidene-2-keto- $N$-benzyl-L-gulonamide as a clear, colorless gum (98\%): ${ }^{1} \mathrm{H}$ NMR (400 MHz, $\mathrm{CDCl}_{3}$ ), $\delta 7.44$ (br s, 1 H, CONHCH 2 ), 7.35-7.20 (m, 5 H, Ar-H), 4.63 (s, 1 H, OCHCH), 4.56-4.46 (m, 2 H, NHCH $2 \mathrm{Ph}$ ), 4.32 (s, 1 H, OCHCH), 4.17 (s, 1 H, OCHCH), 4.07 (ABq, $\left.2 \mathrm{H}, \mathrm{J}=14.7 \mathrm{~Hz}, \mathrm{OCH}_{2} \mathrm{CH}\right)$, 1.58 (s, $3 \mathrm{H}, \mathrm{O}_{2} \mathrm{CCH}_{3}$ ), 1.55 (s, $3 \mathrm{H}, \mathrm{O}_{2} \mathrm{CCH}_{3}$ ), 1.40 (s, $3 \mathrm{H}, \mathrm{O}_{2} \mathrm{CCH}_{3}$ ), 1.09 (s, $3 \mathrm{H}, \mathrm{O}_{2} \mathrm{CCH}_{3}$ ); ${ }^{13} \mathrm{C}$ NMR $\left(100 \mathrm{MHz}, \mathrm{CDCl}_{3}\right) \delta 167.3,137.7,128.6,127.7,127.4,114.6,110.6,97.5,88.0,73.4,72.5,60.0,43.5$, 28.7, 27.1, 25.7, 18.4. FTIR (neat) 2985 (m), 1688 (s), 1521 (m) cm ${ }^{-1}$; HRMS-ES (m/z): $[\mathrm{M}+\mathrm{H}]^{+}$calcd. for $\mathrm{C}_{19} \mathrm{H}_{26} \mathrm{NO}_{6}$ 364.1760; found 364.1766.

Preparation of a 0.7 M Solution of Zirconium Chloride in Acetonitrile. Acetonitrile (28 mL, freshly distilled from calcium hydride) was added via syringe over 15 min to a 50-mL round-bottom flask - cooled to $-78^{\circ} \mathrm{C}$ in a Dry Ice-acetone bath - fitted with a Teflon-coated stir bar and rubber septum and containing solid zirconium chloride $(4.60 \mathrm{~g}, 19.7 \mathrm{mmol})$. A white suspension formed. The reaction flask was removed from the cooling bath. The solid began dissolving as the mixture warmed (dissolution appeared to begin at $\sim 0{ }^{\circ} \mathrm{C}$ ) and the mixture quickly warmed to $40-50{ }^{\circ} \mathrm{C}$. The mixture was maintained at this temperature by gentle heating with a heat gun until the solids had dissolved ( 5-10 min). The resulting clear, colorless solution was allowed to cool, and the cooled solution was stirred at $23^{\circ} \mathrm{C}$ for $30 \mathrm{~min}$. The septum-capped flask containing the clear, colorless solution of zirconium chloride in acetonitrile was stored in a dessicator containing Drierite. Over a 4-month time period, the solution yellowed, but this did not appear to have any effect in transamidation reactions. 


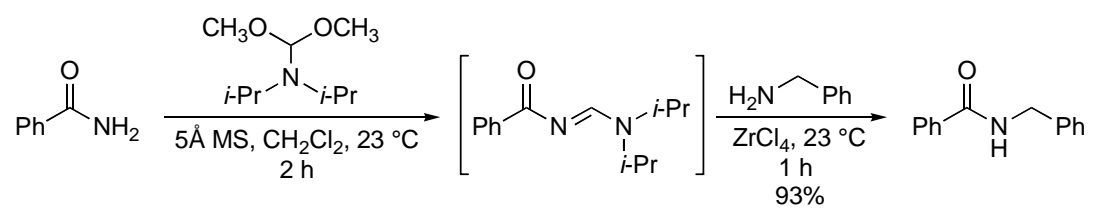

Transamidation of Benzamide with Benzylamine to form $\mathrm{N}$-Benzyl Benzamide using $\mathrm{N}, \mathrm{N}$ Diisopropylformamide Dimethyl Acetal as Activator and Zirconium Chloride as Promoter. A 5-mL, round-bottom flask containing a Teflon-coated stir bar and crushed 5-A MS (170 mg) was evacuated (0.1 $\mathrm{mmHg}$ ), and a good flame was applied for $\sim 2$ min to dry the sieves. The flame was removed, the flask was allowed to cool to $23^{\circ} \mathrm{C}$, and an argon atmosphere was introduced. Benzamide (20.0 mg, $0.165 \mathrm{mmol}$ ) and dichloromethane $(1.7 \mathrm{~mL})$ were added in sequence. The resulting suspension was stirred for $5 \mathrm{~min}$ at $23^{\circ} \mathrm{C}$, then $N, N$-diisopropylformamide dimethyl acetal (DIF-DMA, $43.0 \mu \mathrm{L}, 0.21$ mmol, 1.25 equiv) was added via syringe. After stirring for $2 \mathrm{~h}$ at $23^{\circ} \mathrm{C}$, analysis of the reaction mixture by thin-layer chromatography showed that complete conversion of the starting material to the acyl amidine had occurred (30\% ethyl acetate-hexane, $\mathrm{R}_{f}=0.12$ and 0.48 for benzamide and the acyl amidine, respectively). Benzylamine ( $36 \mu \mathrm{L}$, $0.33 \mathrm{mmol}, 2.0$ equiv) was added to the reaction mixture at this point followed 3 min later by a solution of zirconium chloride in acetonitrile ( $0.7 \mathrm{M}, 120 \mu \mathrm{L}, 0.08 \mathrm{mmol}, 0.5$ equiv). After stirring for $1 \mathrm{~h}$ at $23^{\circ} \mathrm{C}$, the reaction mixture was diluted with ether $(3 \mathrm{~mL}),{ }^{6}$ and the diluted solution was filtered through a pad of Celite. The Celite pad was washed with ether $(3 \times 3 \mathrm{~mL})$, the filtrates were combined, and the combined solution was washed with $0.2 \mathrm{~N}$ aqueous sulfuric acid solution $(10 \mathrm{~mL})$. The aqueous layer was separated and extracted with two 5-mL portions of ether. The ethereal layers were combined, and the combined layers were washed sequentially with saturated aqueous sodium bicarbonate solution $(5 \mathrm{~mL})$ and saturated aqueous sodium chloride solution $(10 \mathrm{~mL})$. After washing, the ethereal solution was dried over anhydrous magnesium sulfate, and the dried solution was concentrated. The residue was purified by flash column chromatography on silica gel (60\% ether-hexane) providing $32.3 \mathrm{mg}$ of $N$-benzyl benzamide ${ }^{7}$ as a white solid (93\%): ${ }^{1} \mathrm{H}$ NMR (400 MHz, $\mathrm{CDCl}_{3}$ ) $\delta$ 7.80-7.78 (m, 2 H, Ar-H), 7.52-7.28 (m, 8 H, Ar-H), 6.55 (br s, $1 \mathrm{H}, \mathrm{CONH}), 4.64$ (d, J = $5.5 \mathrm{~Hz}, 2 \mathrm{H}, \mathrm{CH}_{2} \mathrm{Ph}$ ).

\footnotetext{
${ }_{7}^{6}$ Addition of ether aids in the subsequent filtration of the reaction mixture.

${ }^{7}$ Matsuda, F.; Itoh, S.; Hattori, N.; Yanagiya, M.; Matsumoto, T. Tetrahedron 1985, 41, 3625.
} 


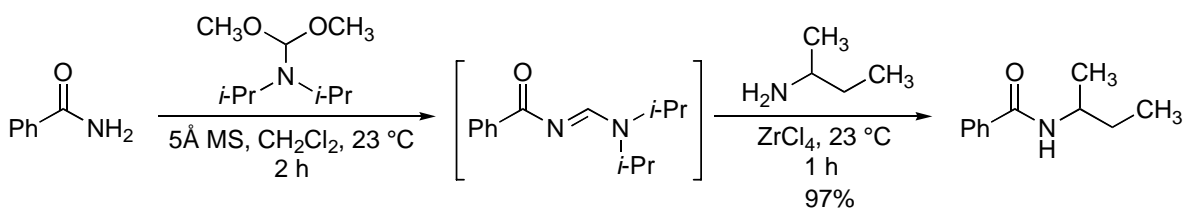

Transamidation of Benzamide with sec-Butylamine to form $\mathrm{N}$-sec-Butyl Benzamide using $\mathrm{N}, \mathrm{N}$ Diisopropylformamide Dimethyl Acetal as Activator and Zirconium Chloride as Promoter. A 10-mL round-bottom flask containing a Teflon-coated stir bar and 5-A MS (330 mg) was evacuated (0.1 mmHg), and a good flame was applied for $\sim 2$ min to dry the sieves. The flame was removed, the flask was allowed to cool to $23{ }^{\circ} \mathrm{C}$, and an argon atmosphere was introduced. Benzamide $(40.0 \mathrm{mg}, 0.330 \mathrm{mmol})$ and dichloromethane $(3.3 \mathrm{~mL})$ were added in sequence. The resulting suspension was stirred for $5 \mathrm{~min}$, and $N, N$-diisopropylformamide dimethyl acetal (DIF-DMA, $84.0 \mu \mathrm{L}, 0.413 \mathrm{mmol}, 1.25$ equiv) was added via syringe. After stirring for $2 \mathrm{~h}$ at $23{ }^{\circ} \mathrm{C}$, analysis of the reaction mixture by thin-layer chromatography showed that complete conversion of the starting material to the acyl amidine had occurred ( $30 \%$ ethyl acetate-hexane, $\mathrm{R}_{f}=0.12$ and 0.48 for benzamide and the acyl amidine, respectively). sec-Butyl amine (67.0 $\mu \mathrm{L}, 0.66 \mathrm{mmol}, 2.0$ equiv) was added to the reaction mixture at this point followed 3 min later by a solution of zirconium chloride in acetonitrile ( $0.7 \mathrm{M}, 190 \mu \mathrm{L}, 0.132 \mathrm{mmol}, 0.4$ equiv). After stirring for $1 \mathrm{~h}$ at $23{ }^{\circ} \mathrm{C}$, the reaction mixture was diluted with ether $(2 \mathrm{~mL})$, and the diluted solution was filtered through a pad of Celite. The Celite pad was washed with ether $(3 \times 3 \mathrm{~mL})$, the filtrates were combined, and the combined solution was washed with $0.2 \mathrm{~N}$ aqueous sulfuric acid solution $(10 \mathrm{~mL})$. The aqueous layer was separated and extracted with two 5-mL portions of ether. The ethereal layers were combined, and the combined layers were washed sequentially with saturated aqueous sodium bicarbonate solution $(5 \mathrm{~mL})$ and saturated aqueous sodium chloride solution $(10 \mathrm{~mL})$. After washing, the ethereal solution was dried over anhydrous magnesium sulfate, and the dried solution was concentrated. The residue was purified by flash column chromatography on silica gel (80\% ether-hexane) to afford $56.7 \mathrm{mg}$ of $\mathrm{N}$-sec-butyl benzamide ${ }^{8}$ as a white solid (97\%): ${ }^{1} \mathrm{H}$ NMR (500 MHz, $\mathrm{CDCl}_{3}$ ) $\delta$ 7.76-7.74 (m, $\left.2 \mathrm{H}, \mathrm{Ar}-\mathbf{H}\right)$, 7.46-7.39 (m, $\left.3 \mathrm{H}, \mathrm{Ar}-\mathbf{H}\right)$, 6.08 (br s, $1 \mathrm{H}, \mathrm{CONH}$ ), 4.10 (sep, J = $7 \mathrm{~Hz}, 1 \mathrm{H}, \mathrm{NHCH}\left(\mathrm{CH}_{3}\right) \mathrm{CH}_{2}$ ), 1.55 (sextet, J = $7 \mathrm{~Hz}, 2 \mathrm{H}, \mathrm{CHCH}_{2^{-}}$ $\left.\mathrm{CH}_{3}\right), 1.21$ (d, J = 6.6 Hz, $\left.3 \mathrm{H}, \mathrm{CHCH}_{3}\right), 0.95\left(\mathrm{t}, \mathrm{J}=7.3 \mathrm{~Hz}, 3 \mathrm{H}, \mathrm{CH}_{2} \mathrm{CH}_{3}\right)$.

\footnotetext{
${ }^{8}$ Tillack, A.; Rudloff, I.; Beller, M. Eur. J. Org. Chem. 2001, 523.
} 


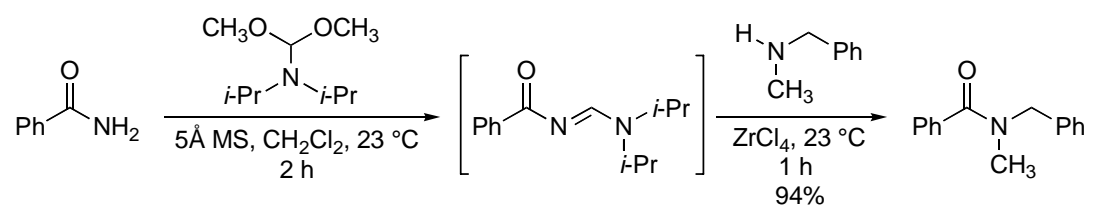

Transamidation of Benzamide with $N$-Benzylmethylamine to form $N$-Benzyl- $N$-methyl Benzamide using $N, N$-Diisopropylformamide Dimethyl Acetal as Activator and Zirconium Chloride as

Promoter. A 10-mL round-bottom flask containing a Teflon-coated stir bar and 5-A MS (330 mg) was evacuated (0.1 mmHg), and a good flame was applied for $\sim 2$ min to dry the sieves. The flame was removed, the flask was allowed to cool to $23{ }^{\circ} \mathrm{C}$, and an argon atmosphere was introduced. Benzamide (40.0 mg, $0.330 \mathrm{mmol}$ ) and dichloromethane $(3.3 \mathrm{~mL}$ ) were added in sequence. The resulting suspension was stirred for $5 \mathrm{~min}$, and $N, N$-diisopropylformamide dimethyl acetal (DIF-DMA, $84.0 \mu \mathrm{L}, 0.413 \mathrm{mmol}$, 1.25 equiv) was added via syringe. After stirring for $2 \mathrm{~h}$ at $23^{\circ} \mathrm{C}$, analysis of the reaction mixture by thinlayer chromatography showed that complete conversion of the starting material to the acyl amidine had occurred (30\% ethyl acetate-hexane, $\mathrm{R}_{f}=0.12$ and 0.48 for benzamide and the acyl amidine, respectively). $N$-Benzylmethylamine (106 $\mu \mathrm{L}, 0.825 \mathrm{mmol}, 2.5$ equiv) was added to the reaction mixture at this point followed 3 min later by a solution of zirconium chloride in acetonitrile $(0.7 \mathrm{M}, 235 \mu \mathrm{L}, 0.165 \mathrm{mmol}, 0.5$ equiv). After stirring for $1 \mathrm{~h}$ at $23^{\circ} \mathrm{C}$, the reaction mixture was diluted with ether ( $\left.2 \mathrm{~mL}\right)$, and the diluted solution was filtered through a pad of Celite. The Celite pad was washed with ether $(3 \times 3 \mathrm{~mL})$, the filtrates were combined, and the combined solution was washed with $0.2 \mathrm{~N}$ aqueous sulfuric acid solution (10 mL). The aqueous layer was separated and extracted with two 5-mL portions of ether. The ethereal layers were combined, and the combined layers were washed sequentially with saturated aqueous sodium bicarbonate solution $(5 \mathrm{~mL})$ and saturated aqueous sodium chloride solution (10 mL). After washing, the ethereal solution was dried over anhydrous magnesium sulfate, and the dried solution was concentrated. The residue was purified by flash column chromatography on silica gel (50\% ether-hexane) to afford $70.0 \mathrm{mg}$ of $\mathrm{N}$ benzyl- $N$-methyl benzamide ${ }^{9}$ as a clear, colorless oil (94\%): ${ }^{1} \mathrm{H}$ NMR (400 MHz, $\left.\mathrm{CDCl}_{3}\right) \delta$ 7.47-7.30 (m, 9 H, Ar-H), 7.19-7.16 (m, 1 H, Ar-H), 4.77 (br s, $0.5 \times 2$ H, NCH $\mathbf{H}_{2} \mathrm{Ph}$ ), 4.52 (br s, $\left.0.5 \times 2 \mathrm{H}, \mathrm{NCH} 2 \mathrm{Ph}\right), 3.03$ (br s, $0.5 \times 3 \mathrm{H}, \mathrm{NCH}_{3}$ ), 2.87 (br s, $0.5 \times 3 \mathrm{H}, \mathrm{NCH}_{3}$ ).

\footnotetext{
${ }^{9}$ Leggio, A.; Liguori, A.; Napoli, A.; Siciliano, C.; Sindona, G. J. Org. Chem. 2001, 66, 2246.
} 


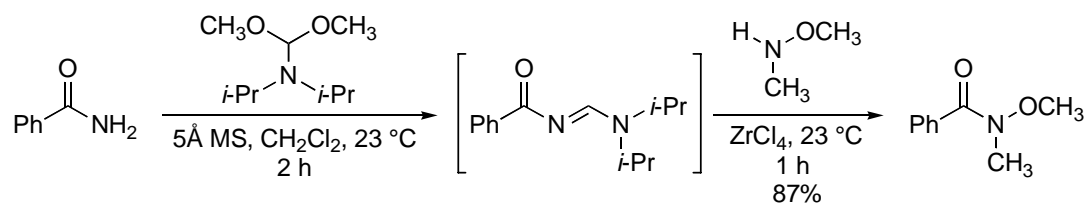

Transamidation of Benzamide with $N, O$-Dimethylhydroxylamine to form $N$-Methoxy- $N$-methyl Benzamide using $N, N$-Diisopropylformamide Dimethyl Acetal as Activator and Zirconium Chloride

as Promoter. A 10-mL round-bottom flask containing a Teflon-coated stir bar and crushed 5-A MS (350 mg) and evacuated (0.1 mmHg), and a good flame was applied for 2 min to dry the sieves. The flame was removed, the flask was allowed to cool to $23^{\circ} \mathrm{C}$, and an argon atmosphere was introduced. Benzamide (40.0 mg, $0.330 \mathrm{mmol}$ ) and dichloromethane $(3.3 \mathrm{~mL}$ ) were added in sequence. The resulting suspension was stirred for $5 \mathrm{~min}$, and $N, N$-diisopropylformamide dimethyl acetal (DIF-DMA, $84.0 \mu \mathrm{L}, 0.413 \mathrm{mmol}$, 1.25 equiv) was added via syringe. After stirring for $2 \mathrm{~h}$ at $23^{\circ} \mathrm{C}$, analysis of the reaction mixture by thinlayer chromatography showed that complete conversion of the starting material to the acyl amidine had occurred (30\% ethyl acetate-hexane, $\mathrm{R}_{f}=0.12$ and 0.48 for benzamide and the acyl amidine, respectively). $N, O$-Dimethylhydroxylamine (72 $\mu \mathrm{L}, 0.99 \mathrm{mmol}, 3.0$ equiv) was added to the reaction mixture at this point followed 3 min later by a solution of zirconium chloride in acetonitrile $(0.7 \mathrm{M}, 235 \mu \mathrm{L}, 0.165 \mathrm{mmol}, 0.5$ equiv). After stirring for $1 \mathrm{~h}$ at $23^{\circ} \mathrm{C}$, the reaction mixture was diluted with ether ( $\left.2 \mathrm{~mL}\right)$, and the diluted solution was filtered through a pad of Celite. The Celite pad was washed with ether $(3 \times 3 \mathrm{~mL})$, the filtrates were combined, and the combined solution was washed with $0.2 \mathrm{~N}$ aqueous sulfuric acid solution (10 mL). The aqueous layer was separated and extracted with two 5-mL portions of ether. The ethereal layers were combined, and the combined layers were washed sequentially with saturated aqueous sodium bicarbonate solution $(5 \mathrm{~mL})$ and saturated aqueous sodium chloride solution (10 mL). After washing, the ethereal solution was dried over anhydrous magnesium sulfate, and the dried solution was concentrated. The residue was purified by flash column chromatography on silica gel (50\% ether-hexane) to afford $47.4 \mathrm{mg}$ of $\mathrm{N}$ methoxy- $N$-methyl benzamide ${ }^{10}$ as a clear, colorless oil (87\%): ${ }^{1} \mathrm{H}$ NMR (500 MHz, $\mathrm{CDCl}_{3}$ ) $\delta 7.65$ (app d,

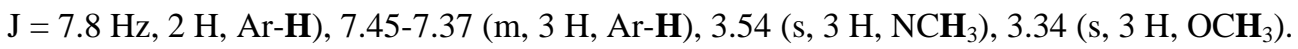

\footnotetext{
${ }^{10}$ Leggio, A.; Liguori, A.; Napoli, A.; Siciliano, C.; Sindona, G. J. Org. Chem. 2001, 66, 2246.
} 


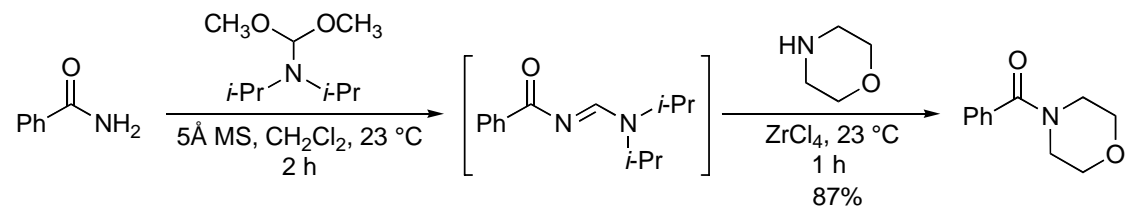

Transamidation of Benzamide with Morpholine to form $N$-Benzoyl Morpholine using $N, N$ Diisopropylformamide Dimethyl Acetal as Activator and Zirconium Chloride as Promoter. A $10-\mathrm{mL}$ round-bottom flask containing a Teflon-coated stir bar and 5-A MS (330 mg) was evacuated (0.1 mmHg), and a good flame was applied for $\sim 2$ min to dry the sieves. The flame was removed, the flask was allowed to cool to $23{ }^{\circ} \mathrm{C}$, and an argon atmosphere was introduced. Benzamide (40.0 mg, $\left.0.330 \mathrm{mmol}\right)$ and dichloromethane $(3.3 \mathrm{~mL})$ were added in sequence. The resulting suspension was stirred for 5 min, and $N, N$-Diisopropylformamide dimethyl acetal (DIF-DMA, $84.0 \mu \mathrm{L}, 0.413 \mathrm{mmol}, 1.25$ equiv) was added via syringe. After stirring for $2 \mathrm{~h}$ at $23{ }^{\circ} \mathrm{C}$, analysis of the reaction mixture by thin-layer chromatography showed that complete conversion of the starting material to the acyl amidine had occurred (30\% ethyl acetate-hexane, $\mathrm{R}_{f}=0.12$ and 0.48 for benzamide and the acyl amidine, respectively). Morpholine (58.0 $\mu \mathrm{L}, 0.66 \mathrm{mmol}$ ) was added to the reaction mixture at this point followed 3 min later by a solution of zirconium chloride in acetonitrile $\left(0.7 \mathrm{M}, 190 \mu \mathrm{L}, 0.132 \mathrm{mmol}, 0.5\right.$ equiv). After stirring for $1 \mathrm{~h}$ at $23^{\circ} \mathrm{C}$, the reaction mixture was diluted with ether $(2 \mathrm{~mL})$, and the diluted solution was filtered through a pad of Celite. The Celite pad was washed with ether $(3 \times 3 \mathrm{~mL})$, the filtrates were combined, and the combined solution was washed with $0.2 \mathrm{~N}$ aqueous sulfuric acid solution $(10 \mathrm{~mL})$. The aqueous layer was separated and extracted with two 5-mL portions of ether. The ethereal layers were combined, and the combined layers were washed sequentially with saturated aqueous sodium bicarbonate solution (5 mL) and saturated aqueous sodium chloride solution $(10 \mathrm{~mL})$. After washing, the ethereal solution was dried over anhydrous magnesium sulfate, and the dried solution was concentrated. The residue was purified by flash column chromatography on silica gel (80\% ether-hexane) to afford $54.5 \mathrm{mg}$ of $N$-benzoyl morpholine ${ }^{11}$ as a white solid (87\%): ${ }^{1} \mathrm{H}$ NMR (500 MHz, $\mathrm{CDCl}_{3}$ ) $\delta$ 7.41-7.38 (m, $\left.5 \mathrm{H}, \mathrm{Ar}-\mathbf{H}\right)$, 3.43-3.75 (m, 8 H, CH ).

\footnotetext{
${ }^{11}$ Kondo, K.; Sekimoto, E.; Nakao, J.; Murakami, Y. Tetrahedron 2000, 56, 5843.
} 


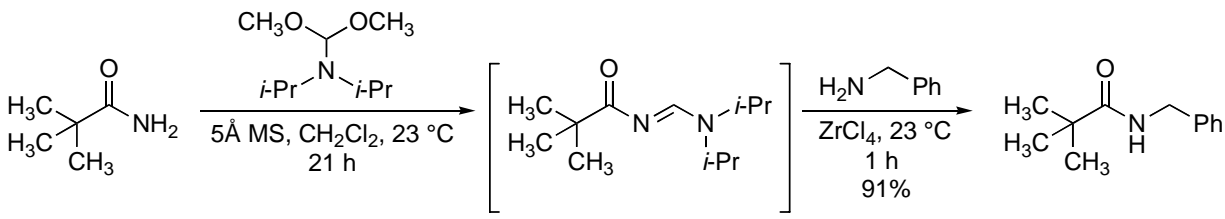

Transamidation of Pivalamide with Benzylamine to form $\mathrm{N}$-Benzyl Pivalamide using $\mathrm{N}, \mathrm{N}$ Diisopropylformamide Dimethyl Acetal as Activator and Zirconium Chloride as Promoter. A 10-mL round-bottom flask containing a Teflon-coated stir bar and crushed 5-A MS (400 mg) was evacuated (0.1 $\mathrm{mmHg}$ ), and a good flame was applied for $\sim 2$ min to dry the sieves. The flame was removed, the flask was allowed to cool to $23{ }^{\circ} \mathrm{C}$, and an argon atmosphere was introduced. Pivalamide (40.0 mg, $\left.0.395 \mathrm{mmol}\right)$ and dichloromethane $(4.0 \mathrm{~mL})$ were added in sequence. The resulting suspension was stirred for $5 \mathrm{~min}$, and $N, N$-Diisopropylformamide dimethyl acetal (DIF-DMA, $84.0 \mu \mathrm{L}, 0.413 \mathrm{mmol}, 1.25$ equiv) was added via syringe. The mixture was stirred for $24 \mathrm{~h}$ at $23{ }^{\circ} \mathrm{C} .{ }^{12}$ Benzylamine ( $86 \mu \mathrm{L}, 0.79 \mathrm{mmol}, 2$ equiv) was added to the reaction mixture at this point followed 3 min later by a solution of zirconium chloride in acetonitrile ( $0.7 \mathrm{M}, 226 \mu \mathrm{L}, 0.158 \mathrm{mmol}, 0.5$ equiv). After stirring for $1 \mathrm{~h}$ at $23{ }^{\circ} \mathrm{C}$, the reaction mixture was diluted with ether (2 mL), and the diluted solution was filtered through a pad of Celite. The Celite pad was washed with ether ( $3 \times 3 \mathrm{~mL}$ ), the filtrates were combined, and the combined solution was washed with $0.2 \mathrm{~N}$ aqueous sulfuric acid solution $(10 \mathrm{~mL})$. The aqueous layer was separated and extracted with two 5-mL portions of ether. The ethereal layers were combined, and the combined layers were washed sequentially with saturated aqueous sodium bicarbonate solution $(5 \mathrm{~mL})$ and saturated aqueous sodium chloride solution (10 mL). After washing, the ethereal solution was dried over anhydrous magnesium sulfate, and the dried solution was concentrated. The residue was purified by flash column chromatography on silica gel (50\% ether-hexane) to afford $68.5 \mathrm{mg}$ of $N$-benzyl pivalamide ${ }^{13}$ as a white solid (91\%): ${ }^{1} \mathrm{H}$ NMR (500 MHz, $\mathrm{CDCl}_{3}$ ) $\delta$ 7.36-7.27 (m, 5 H, Ar-H), 5.89 (br s, 1 H, NH), 4.44 (d, J = 5.6 Hz, 2 H, NHCH $\mathrm{H}_{2} \mathrm{Ph}$ ), 1.23 (s, $9 \mathrm{H}$ $\left.\mathrm{CH}\left(\mathrm{CH}_{3}\right)_{3}\right)$.

\footnotetext{
12 The reaction was stirred for $24 \mathrm{~h}$ to ensure complete formation of the acyl amidine.

${ }^{13}$ Kondo, K.; Iida, T.; Fujita, H.; Suzuki, T.; Yamaguchi, K.; Murakami, Y. Tetrahedron 2000, 56, 8883.
} 


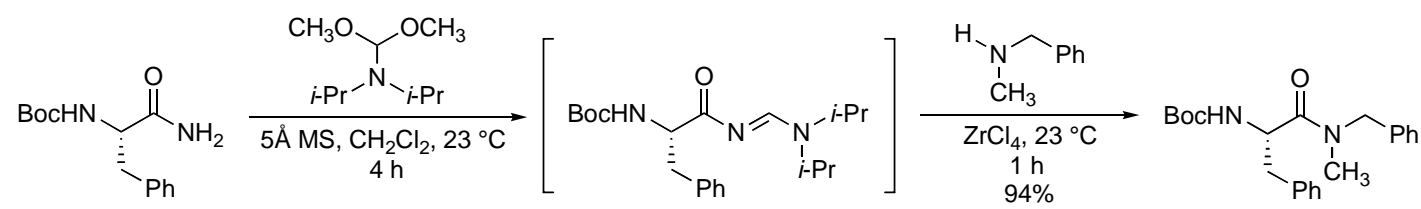

Transamidation of $N^{\alpha}$-(tert-Butoxycarbonyl)-L-phenylalaninamide with $N$-Benzylmethylamine to form $\quad N^{\alpha}$-(tert-Butoxycarbonyl)-L-phenylalanine- $N$-benzyl- $N$-methylamide $\quad$ using $\quad N, N$ Diisopropylformamide Dimethyl Acetal as Activator and Zirconium Chloride as Promoter. A 10-mL round-bottom flask containing a Teflon-coated stir bar and crushed 5-A MS (190 mg) was evacuated (0.1 mmHg), and a good flame was applied for $~ 2$ min to dry the sieves. The flame was removed, the flask was allowed to cool to $23{ }^{\circ} \mathrm{C}$, and an argon atmosphere was introduced. $N^{\alpha}$-(tert-Butoxycarbonyl)-Lphenylalaninamide $(50.0 \mathrm{mg}, 0.189 \mathrm{mmol})$ and dichloromethane $(1.9 \mathrm{~mL})$ were added in sequence, The resulting suspension was stirred for $5 \mathrm{~min}$, and $N, N$-diisopropylformamide dimethyl acetal (DIF-DMA, $48.0 \mu \mathrm{L}, 0.234 \mathrm{mmol}, 1.25$ equiv) was added via syringe. After stirring for $4 \mathrm{~h}$ at $23{ }^{\circ} \mathrm{C}$, analysis of the reaction mixture by thin-layer chromatography showed that complete conversion of the starting material to the acyl amidine had occurred (50\% ethyl acetate-hexane, $\mathrm{R}_{f}=0.18$ and 0.42 for the primary amide and the acyl amidine, respectively). $N$-Benzylmethylamine (61 $\mu \mathrm{L}, 0.47 \mathrm{mmol}, 2.5$ equiv) was added to the reaction mixture at this point followed 3 min later by a solution of zirconium chloride in acetonitrile (0.7 M, 135 $\mu \mathrm{L}, 0.09 \mathrm{mmol}, 0.5$ equiv). After stirring for $1 \mathrm{~h}$ at $23^{\circ} \mathrm{C}$, the reaction mixture was diluted with ether $(2$ $\mathrm{mL}$ ), and the diluted solution was filtered through a pad of Celite. The Celite pad was washed with ether (3 $\times 3 \mathrm{~mL}$ ), the filtrates were combined, and the combined solution was washed with $0.2 \mathrm{~N}$ aqueous sulfuric acid solution $(10 \mathrm{~mL})$. The aqueous layer was separated and extracted with two 5-mL portions of ether. The ethereal layers were combined, and the combined layers were washed sequentially with saturated aqueous sodium bicarbonate solution $(5 \mathrm{~mL})$ and saturated aqueous sodium chloride solution (10 mL). After washing, the ethereal solution was dried over anhydrous magnesium sulfate, and the dried solution was concentrated. The residue was purified by flash column chromatography on silica gel (40\% ether-hexane) to afford $65.3 \mathrm{mg}$ of $N^{\alpha}$-(tert-butoxycarbonyl)-L-phenylalanine- $N$-benzyl- $N$-methylamide ${ }^{14}$ as a white solid (94\%): ${ }^{1} \mathrm{H}$ NMR (500 MHz, $\left.\mathrm{CDCl}_{3}\right) \delta$ 7.28-6.98 (m, $\left.10 \mathrm{H}, \mathrm{Ar}-\mathrm{H}\right), 5.46$ (d, J = 8.8 Hz, $\left.0.75 \times 1 \mathrm{H}, \mathrm{BocNH}\right)$, 5.39 (d, J = 8.8 Hz, $0.25 \times 1$ H, BocNH), 4.88 (dt, J = 7.3 Hz, 1 H, NHCHCO), 4.55 (A of ABX, J = 14.6

\footnotetext{
${ }^{14}$ Hagiwara, D.; Miyake, H.; Morimoto, H.; Murai, M.; Fujii, T.; Matsuo, M. J. Med. Chem. 1992, 35, 3184.
} 
$\left.\mathrm{Hz}, 0.75 \times 1 \mathrm{H}, \mathrm{CHCH}_{2} \mathrm{Ph}\right), 4.44\left(\mathrm{~B}\right.$ of $\left.\mathrm{ABX}, \mathrm{J}=14.6 \mathrm{~Hz}, 0.75 \times 1 \mathrm{H}, \mathrm{CHCH}_{2} \mathrm{Ph}\right), 4.36(\mathrm{~A}$ of $\mathrm{ABX}, \mathrm{J}=$ 16.6 Hz, $\left.0.25 \times 1 \mathrm{H}, \mathrm{CHCH}_{2} \mathrm{Ph}\right), 4.12\left(\mathrm{~B}\right.$ of ABX, J = 16.6 Hz, $\left.0.25 \times 1 \mathrm{H}, \mathrm{CHCH}_{2} \mathrm{Ph}\right), 3.10$ (d, J = 7.3 Hz, 2H, $\left.\mathrm{CH}_{2} \mathrm{Ph}\right), 2.83\left(\mathrm{~s}, 0.25 \times 3 \mathrm{H}, \mathrm{NCH}_{3}\right), 2.62\left(\mathrm{~s}, 0.75 \times 3 \mathrm{H}, \mathrm{NCH}_{3}\right), 1.43\left(\mathrm{~s}, 0.75 \times 9 \mathrm{H}, \mathrm{CH}\left(\mathrm{CH}_{3}\right)_{4}\right), 1.39$ $\left(\mathrm{s}, 0.25 \times 9 \mathrm{H}, \mathrm{CH}\left(\mathrm{CH}_{3}\right)_{3}\right)$.

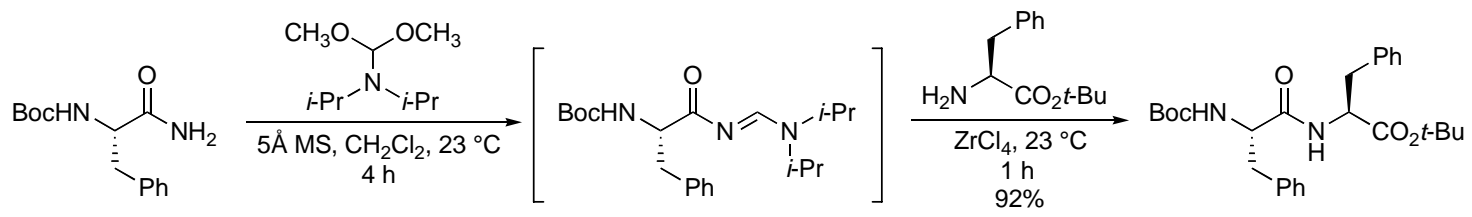

Transamidation of $N^{\alpha}$-(tert-Butoxycarbonyl)-L-phenylalaninamide with L-Phenylalanine-tert-butyl ester to form Boc-L-Phe-L-Phe-Ot-Bu using $N, N$-Diisopropylformamide Dimethyl Acetal as Activator and Zirconium Chloride as Promoter. A 10-mL round-bottom flask containing a Tefloncoated stir bar and crushed 5-A MS (190 mg) was evacuated (0.1 mmHg), and a good flame was applied for $\sim 2$ min to dry the sieves. The flame was removed, the flask was allowed to cool to $23{ }^{\circ} \mathrm{C}$, and an argon atmosphere was introduced. $N^{\alpha}$-(tert-Butoxycarbonyl)-L-phenylalaninamide (50.0 mg, $\left.0.189 \mathrm{mmol}\right)$ and dichloromethane $(1.9 \mathrm{~mL})$ were added in sequence, The resulting suspension was stirred for 5 min, and $N, N$-diisopropylformamide dimethyl acetal (DIF-DMA, $48.0 \mu \mathrm{L}, 0.234 \mathrm{mmol}, 1.25$ equiv) was added via syringe. After stirring for $4 \mathrm{~h}$ at $23^{\circ} \mathrm{C}$, analysis of the reaction mixture by thin-layer chromatography showed that complete conversion of the starting material to the acyl amidine had occurred (50\% ethyl acetate-hexane, $\mathrm{R}_{f}=0.18$ and 0.42 for the primary amide and the acyl amidine, respectively). LPhenylalanine-tert-butyl ester (83 $\mathrm{mg}, 0.38 \mathrm{mmol}, 2.0$ equiv) was added to the reaction mixture at this point followed 3 min later by a solution of zirconium chloride in acetonitrile $(0.7 \mathrm{M}, 135 \mu \mathrm{L}, 0.09 \mathrm{mmol}, 0.5$ equiv). After stirring for $1 \mathrm{~h}$ at $23^{\circ} \mathrm{C}$, the reaction mixture was diluted with ether ( $\left.2 \mathrm{~mL}\right)$, and the diluted solution was filtered through a pad of Celite. The Celite pad was washed with ether $(3 \times 3 \mathrm{~mL})$, the filtrates were combined, and the combined solution was washed with $0.2 \mathrm{~N}$ aqueous sulfuric acid solution (10 mL). The aqueous layer was separated and extracted with two 5-mL portions of ether. The ethereal layers were combined, and the combined layers were washed sequentially with saturated aqueous sodium bicarbonate solution $(5 \mathrm{~mL})$ and saturated aqueous sodium chloride solution (10 mL). After washing, the ethereal 
solution was dried over anhydrous magnesium sulfate, and the dried solution was concentrated. The residue was purified by flash column chromatography on silica gel (40\% ether-hexane) to afford $81.5 \mathrm{mg}$ of Boc-LPhe-L-Phe-Ot-Bu as a white solid (92\%): ${ }^{1} \mathrm{H}$ NMR (400 MHz, $\left.\mathrm{CDCl}_{3}\right), \delta$ 7.29-7.18 (m, $\left.8 \mathrm{H}, \mathrm{Ar}-\mathrm{H}\right)$, 7.067.04 (m, 2 H, Ar-H), 6.34 (br d, J = 4.8 Hz, 1 H, CONHCH), 4.98 (br s, 1 H, BocNH), 4.64 (app d, J = 5.6 Hz, 1 H, NHCHCO), 4.35 (br s, 1 H, NHCHCO), 3.05-3.01 (m, 4 H, $\mathrm{CCH}_{2} \mathrm{Ph}$ ), 1.40 (s, $\left.9 \mathrm{H}, \mathrm{CH}\left(\mathrm{CH}_{3}\right)_{3}\right)$, 1.35 (s, $\left.9 \mathrm{H}, \mathrm{CH}\left(\mathrm{CH}_{3}\right)_{3}\right) ;{ }^{13} \mathrm{C}$ NMR $\left(100 \mathrm{MHz}, \mathrm{CDCl}_{3}\right) \delta$ 170.5, 169.9, 155.2, 136.5, 136.0, 129.5, 129.3, 128.6, 128.3, 126.9, 82.3, 80.6, 55.7, 53.6, 38.3, 38.1, 28.2, 27.8; IR (neat) 3421 (vw), 3323 (vw), 2983 (w), 1721 (m), 1671 (m), 1497 (m), 1368 (m), 1156 (s), 905 (vs) cm-1; HRMS-ES (m/z): [M + H] calcd. for $\mathrm{C}_{27} \mathrm{H}_{37} \mathrm{~N}_{2} \mathrm{O}_{5}$ 469.2602; found 469.2681.

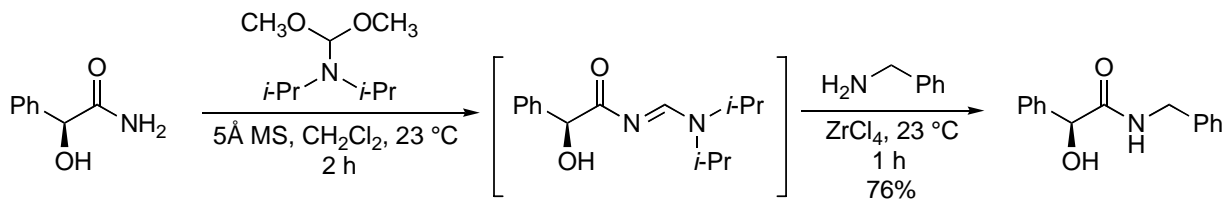

Transamidation of (S)-Mandelamide with Benzylamine to form $\mathrm{N}$-Benzyl (S)-Mandelamide using $\mathrm{N}, \mathrm{N}$-Diisopropylformamide Dimethyl Acetal as Activator and Zirconium Chloride as Promoter. A 10-mL round-bottom flask containing a Teflon-coated stir bar and 5-A MS (330 mg) was evacuated (0.1 $\mathrm{mmHg}$ ), and a good flame was applied for $\sim 2$ min to dry the sieves. The flame was removed, the flask was allowed to cool to $23{ }^{\circ} \mathrm{C}$, and an argon atmosphere was introduced. (S)-Mandelamide (50.0 $\mathrm{mg}, 0.331$ mmol) and dichloromethane $(3.3 \mathrm{~mL})$ were added in sequence. The resulting suspension was stirred for 5 min, $N, N$-diisopropylformamide dimethyl acetal (DIF-DMA, $83.0 \mu \mathrm{L}, 0.414 \mathrm{mmol}, 1.25$ equiv) was added via syringe. After stirring for $2 \mathrm{~h}$ at $23^{\circ} \mathrm{C}$, analysis of the reaction mixture by thin-layer chromatography showed that complete conversion of the starting material to the acyl amidine had occurred ( $80 \%$ ethyl acetate-hexane, $\mathrm{R}_{f}=0.27$ and 0.64 for $(S)$-mandelamide and the acyl amidine, respectively). Benzylamine (90.0 $\mu \mathrm{L}, 0.827 \mathrm{mmol}, 2.5$ equiv) was added to the reaction mixture at this point followed 3 min later by a solution of zirconium chloride in acetonitrile ( $0.7 \mathrm{M}, 235 \mu \mathrm{L}, 0.165 \mathrm{mmol}, 0.5$ equiv). After stirring for $1 \mathrm{~h}$ at $23{ }^{\circ} \mathrm{C}$, the reaction mixture was diluted with ether $(2 \mathrm{~mL})$, and the diluted solution was filtered through a pad of Celite. The Celite pad was washed with ether $(3 \times 3 \mathrm{~mL})$, the filtrates were combined, and the combined solution was washed with $0.2 \mathrm{~N}$ aqueous sulfuric acid solution $(10 \mathrm{~mL})$. The aqueous layer was 
separated and extracted with two 5-mL portions of ether. The ethereal layers were combined, and the combined layers were washed sequentially with saturated aqueous sodium bicarbonate solution $(5 \mathrm{~mL})$ and saturated aqueous sodium chloride solution $(10 \mathrm{~mL})$. After washing, the ethereal solution was dried over anhydrous magnesium sulfate, and the dried solution was concentrated. The residue was purified by flash column chromatography on silica gel (70\% ether-hexane) to afford $61.0 \mathrm{mg}$ of $N$-benzyl (S)-mandelamide ${ }^{15}$ as a white solid (76\%): ${ }^{1} \mathrm{H}$ NMR (500 MHz, $\left.\mathrm{CDCl}_{3}\right) \delta$ 7.39-7.23 (m, $\left.8 \mathrm{H}, \mathrm{Ar}-\mathbf{H}\right)$, 7.18-7.16 (m, $\left.2 \mathrm{H}, \mathrm{Ar}-\mathbf{H}\right)$, 6.88 (br s, 1 H, CONH), 5.01 (s, 1 H, HOCHCO), 4.38 (dd, J = 5.9, 2.9 Hz, 2 H, CH $\mathbf{H}_{2} \mathrm{Ph}$ ).

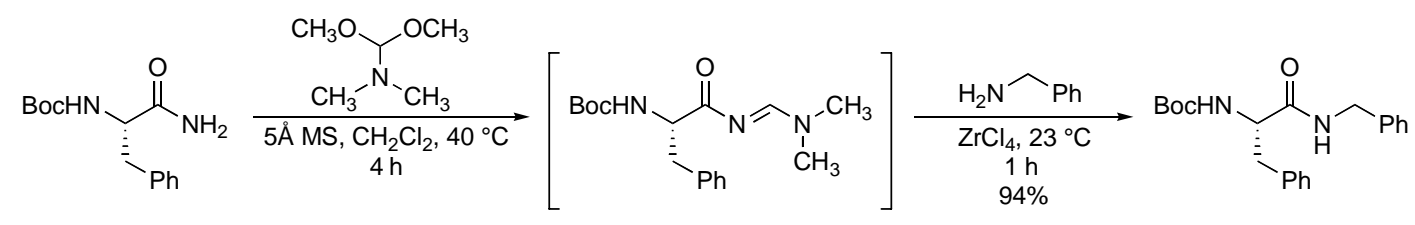

Transamidation of $N^{\alpha}$-(tert-Butoxycarbonyl)-L-phenylalaninamide with Benzylamine to form $N^{\alpha}$ (tert-Butoxycarbonyl)-L-phenylalanine- $N$-benzylamide using $N, N$-Dimethylformamide Dimethyl Acetal as Activator and Zirconium Chloride as Promoter. A 10-mL round-bottom flask containing a Teflon-coated stir bar and crushed 5-A MS (190 mg) was evacuated $(0.1 \mathrm{mmHg})$, and a good flame was applied for $\sim 2$ min to dry the sieves. The flame was removed, the flask was allowed to cool to $23{ }^{\circ} \mathrm{C}$, and an argon atmosphere was introduced. $N^{\alpha}$-(tert-Butoxycarbonyl)-L-phenylalaninamide (50.0 mg, 0.189 mmol) and dichloromethane $(1.9 \mathrm{~mL})$ were added in sequence. After stirring for 5 min at $23{ }^{\circ} \mathrm{C}, \mathrm{N}, \mathrm{N}$ dimethylformamide dimethyl acetal (DMF-DMA, $33.0 \mu \mathrm{L}, 0.25 \mathrm{mmol}, 1.3$ equiv) was added via syringe, and the resulting mixture was heated to reflux. After stirring at reflux for $4 \mathrm{~h}$, analysis of the reaction mixture by thin-layer chromatography showed that complete conversion of the starting material to the acyl amidine had occurred (80\% ethyl acetate-hexane, $\mathrm{R}_{f}=0.44$ and 0.38 for the primary amide and the acyl amidine, respectively), and the mixture was allowed to cool to $23^{\circ} \mathrm{C}$. Benzylamine ( $41 \mu \mathrm{L}, 0.38 \mathrm{mmol}, 2.0$ equiv) was added to the reaction mixture at this point followed 3 min later by a solution of zirconium chloride in acetonitrile $\left(0.7 \mathrm{M}, 135 \mu \mathrm{L}, 0.095 \mathrm{mmol}, 0.5\right.$ equiv). After stirring for $1 \mathrm{~h}$ at $23^{\circ} \mathrm{C}$, the reaction mixture was diluted with ether $(2 \mathrm{~mL})$, and the diluted solution was filtered through a pad of Celite. The Celite pad was washed with ether $(3 \times 3 \mathrm{~mL})$, the filtrates were combined, and the combined solution was

${ }^{15}$ Kolasa, T.; Miller, M. J. J. Org. Chem. 1987, 52, 4978. 
washed with $0.2 \mathrm{~N}$ aqueous sulfuric acid solution $(10 \mathrm{~mL})$. The aqueous layer was separated and extracted with two 5-mL portions of ether. The ethereal layers were combined, and the combined layers were washed sequentially with saturated aqueous sodium bicarbonate solution $(5 \mathrm{~mL})$ and saturated aqueous sodium chloride solution $(10 \mathrm{~mL})$. After washing, the ethereal solution was dried over anhydrous magnesium sulfate, and the dried solution was concentrated. The residue was purified by flash column chromatography on silica gel (60\% ether-hexane) to afford $63.0 \mathrm{mg}$ of $N^{\alpha}$-(tert-butoxycarbonyl)-L-phenylalanine- $N$ benzylamide ${ }^{16}$ as a white solid (94\%): ${ }^{1} \mathrm{H}$ NMR $\left(400 \mathrm{MHz}, \mathrm{CDCl}_{3}\right) \delta$ 7.28-7.17 (m, 8H, Ar-H), 7.08 (br s, 2 H, Ar-H), 6.31 (br t, J = 5.6 Hz, 1 H, CONHCH${ }_{2}$ ), 4.38-3.28 (m, 3 H, NHCHCO and $\mathrm{NHCH}_{2} \mathrm{Ph}$ ), 3.07 (d, J $\left.=6.4 \mathrm{~Hz}, 2 \mathrm{H}, \mathrm{CHCH}_{2} \mathrm{Ph}\right), 1.38\left(\mathrm{~s}, 9 \mathrm{H}, \mathrm{CH}\left(\mathrm{CH}_{3}\right)_{3}\right)$.

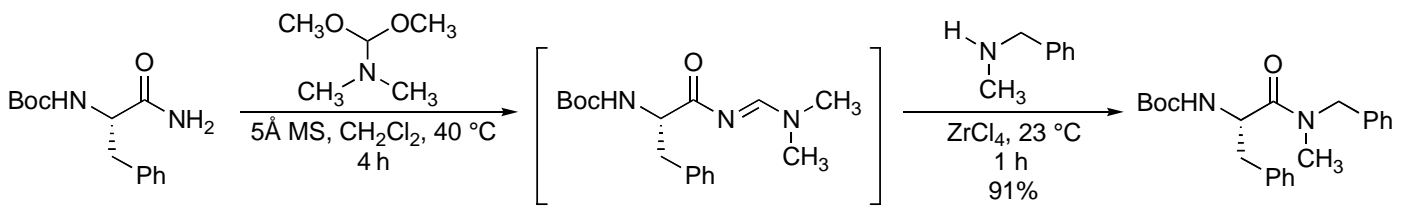

Transamidation of $N^{\alpha}$-(tert-Butoxycarbonyl)-L-phenylalaninamide with $N$-Benzylmethylamine to form $\quad N^{\alpha}$-(tert-Butoxycarbonyl)-L-phenylalanine- $N$-benzyl- $N$-methylamide $\quad$ using $\quad N, N$ Dimethylformamide Dimethyl Acetal as Activator and Zirconium Chloride as Promoter. A 10-mL round-bottom flask containing a Teflon-coated stir bar and crushed 5-A MS (220 mg) was evacuated (0.1 $\mathrm{mmHg}$ ), and a good flame was applied for $\sim 2$ min to dry the sieves. The flame was removed, the flask was allowed to cool to $23{ }^{\circ} \mathrm{C}$, and an argon atmosphere was introduced. $N^{\alpha}$-(tert-Butoxycarbonyl)-Lphenylalaninamide (52.4 mg, $0.198 \mathrm{mmol})$ and dichloromethane $(2.0 \mathrm{~mL})$ were added in sequence. After stirring for $5 \mathrm{~min}$ at $23{ }^{\circ} \mathrm{C}$, and $N, N$-dimethylformamide dimethyl acetal (DMF-DMA, $34.0 \mu \mathrm{L}, 0.256$ mmol, 1.3 equiv) was added via syringe, and the resulting mixture was heated to reflux. After stirring at reflux for $4 \mathrm{~h}$, analysis of the reaction mixture by thin-layer chromatography showed that complete conversion of the starting material to the acyl amidine had occurred ( $80 \%$ ethyl acetate-hexane, $\mathrm{R}_{f}=0.44$ and 0.38 for the primary amide and the acyl amidine, respectively), and the mixture was allowed to cool to $23{ }^{\circ} \mathrm{C}$. $N$-Benzylmethylamine (76 $\mu \mathrm{L}, 0.59 \mathrm{mmol}, 3.0$ equiv) was added to the reaction mixture at this point

\footnotetext{
${ }^{16}$ Fujita, Y.; Tsuda, Y.; Li, T.; Motoyama, T.; Takahashi, M.; Shimizu, Y.; Yokoi, T.; Sasaki, Y.; Ambo, A.; Kita, A.; Jinsmaa, Y.; Bryant, S. D.; Lazarus, L. H.; Okada, Y. J. Med. Chem. 2004, 47, 3591.
} 
followed 3 min later by a solution of zirconium chloride in acetonitrile $(0.7 \mathrm{M}, 140 \mu \mathrm{L}, 0.098 \mathrm{mmol}, 0.5$ equiv). After stirring for $1 \mathrm{~h}$ at $23^{\circ} \mathrm{C}$, the reaction mixture was diluted with ether $(2 \mathrm{~mL})$, and the diluted solution was filtered through a pad of Celite. The Celite pad was washed with ether $(3 \times 3 \mathrm{~mL})$, the filtrates were combined, and the combined solution was washed with $0.2 \mathrm{~N}$ aqueous sulfuric acid solution $(10 \mathrm{~mL})$. The aqueous layer was separated and extracted with two 5-mL portions of ether. The ethereal layers were combined, and the combined layers were washed sequentially with saturated aqueous sodium bicarbonate solution $(5 \mathrm{~mL})$ and saturated aqueous sodium chloride solution $(10 \mathrm{~mL})$. After washing, the ethereal solution was dried over anhydrous magnesium sulfate, and the dried solution was concentrated. The residue was purified by flash column chromatography on silica gel (30\% ethyl acetate-hexane) to afford $66.1 \mathrm{mg}$ of $N^{\alpha}$-(tert-butoxycarbonyl)-L-phenylalanine- $N$-benzyl- $N$-methylamide ${ }^{11}$ as a clear oil (91\%).

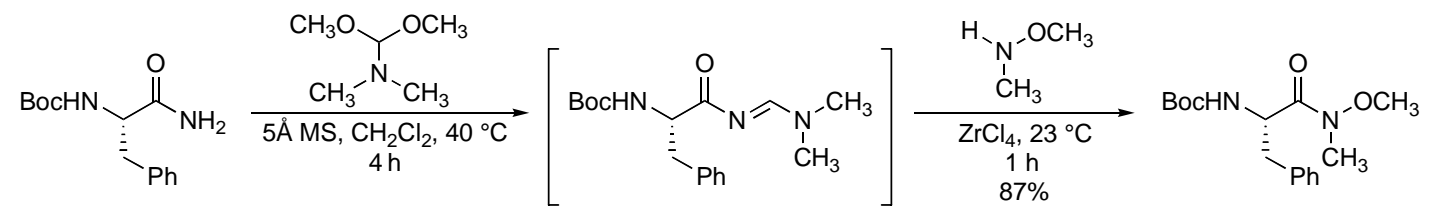

Transamidation of $\quad N^{\alpha}$-(tert-Butoxycarbonyl)-L-phenylalaninamide with $\quad N, O$ Dimethylhydroxylamine to form $\quad N^{\alpha}$-(tert-Butoxycarbonyl)-L-phenylalanine- $N$-methoxy- $N$ methylamide using $N, N$-Dimethylformamide Dimethyl Acetal as Activator and Zirconium Chloride as Promoter. A 10-mL round-bottom flask containing a Teflon-coated stir bar and crushed 5-A MS (215 $\mathrm{mg}$ ) was evacuated $(0.1 \mathrm{mmHg})$, and a good flame was applied for $\sim 2$ min to dry the sieves. The flame was removed, the flask was allowed to cool to $23{ }^{\circ} \mathrm{C}$, and an argon atmosphere was introduced. $N^{\alpha}$-(tertButoxycarbonyl)-L-phenylalaninamide (55.0 mg, $0.208 \mathrm{mmol}$ ) and dichloromethane (2.1 mL) were added in sequence. After stirring for 5 min at $23{ }^{\circ} \mathrm{C}, \mathrm{N}, \mathrm{N}$-dimethylformamide dimethyl acetal (DMF-DMA, 36.0 $\mu \mathrm{L}, 0.271 \mathrm{mmol}, 1.3$ equiv) was added via syringe, and the resulting mixture was heated to reflux. After stirring at reflux for $4 \mathrm{~h}$, analysis of the reaction mixture by thin-layer chromatography showed that complete conversion of the starting material to the acyl amidine had occurred (80\% ethyl acetate-hexane, $\mathrm{R}_{f}=0.44$ and 0.38 for the primary amide and the acyl amidine, respectively), and the mixture was allowed to cool to $23^{\circ} \mathrm{C}$. $N, O$-Dimethylhydroxylamine ( $46 \mu \mathrm{L}, 0.62 \mathrm{mmol}$, 3.0 equiv) was added to the reaction mixture at this point followed 3 min later by a solution of zirconium chloride in acetonitrile $(0.7 \mathrm{M}, 150$ 
$\mu \mathrm{L}, 0.104 \mathrm{mmol}, 0.5$ equiv). After stirring for $1 \mathrm{~h}$ at $23^{\circ} \mathrm{C}$, the reaction mixture was diluted with ether (2 $\mathrm{mL}$ ), and the diluted solution was filtered through a pad of Celite. The Celite pad was washed with ether (3 $\times 3 \mathrm{~mL}$ ), the filtrates were combined, and the combined solution was washed with $0.2 \mathrm{~N}$ aqueous sulfuric acid solution $(10 \mathrm{~mL})$. The aqueous layer was separated and extracted with two 5-mL portions of ether. The ethereal layers were combined, and the combined layers were washed sequentially with saturated aqueous sodium bicarbonate solution $(5 \mathrm{~mL})$ and saturated aqueous sodium chloride solution $(10 \mathrm{~mL})$. After washing, the ethereal solution was dried over anhydrous magnesium sulfate, and the dried solution was concentrated. The residue was purified by flash column chromatography on silica gel (30\% ethyl acetatehexane) to afford $55.6 \mathrm{mg}$ of $N^{\alpha}$-(tert-butoxycarbonyl)-L-phenylalanine- $N$-methoxy- $N$-methylamide ${ }^{17}$ as a clear oil (87\%): ${ }^{1} \mathrm{H}$ NMR (500 MHz, $\mathrm{CDCl}_{3}$ ) $\delta$ 7.29-7.16 (m, $\left.5 \mathrm{H}, \mathrm{Ar}-\mathrm{H}\right), 5.16$ (br d, J = 7.3 Hz, $1 \mathrm{H}$, BocNHCH), 4.95 (br d, J = 5.9 Hz, 1 H, NHCHCO), 3.65 (s, 3 H, NCH ), 3.16 (s, 3 H, OCH OC $_{3}, 04$ (dd, J = 13.2, $5.9 \mathrm{~Hz}, 1 \mathrm{H}, \mathrm{CHCH}_{2} \mathrm{Ph}$ ), 2.87 (dd, J = 13.0, $\left.7.3 \mathrm{~Hz}, 1 \mathrm{H}, \mathrm{CHCH}_{2} \mathrm{Ph}\right), 1.38\left(\mathrm{~s}, 9 \mathrm{H}, \mathrm{CH}\left(\mathrm{CH}_{3}\right)_{3}\right)$.

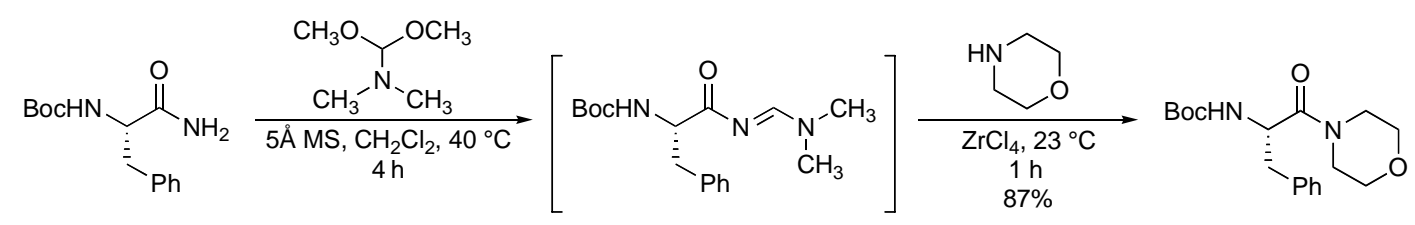

Transamidation of $N^{\alpha}$-(tert-Butoxycarbonyl)-L-phenylalaninamide with Morpholine to form $N^{\alpha}$-(tertButoxycarbonyl)-L-phenylalanine- $N$-morpholinamide using $N, N$-Dimethylformamide Dimethyl Acetal as Activator and Zirconium Chloride as Promoter. A 10-mL round-bottom flask containing a Teflon-coated stir bar and crushed 5-A MS (210 mg) was evacuated $(0.1 \mathrm{mmHg})$, and a good flame was applied for $\sim 2$ min to dry the sieves. The flame was removed, the flask was allowed to cool to $23^{\circ} \mathrm{C}$, and an argon atmosphere was introduced. $N^{\alpha}$-(tert-Butoxycarbonyl)-L-phenylalaninamide (52.0 mg, 0.196 mmol) and dichloromethane $(2.0 \mathrm{~mL})$ were added in sequence. After stirring for 5 min at $23{ }^{\circ} \mathrm{C}, \mathrm{N}, \mathrm{N}$ dimethylformamide dimethyl acetal (DMF-DMA, $34.0 \mu \mathrm{L}, 0.256 \mathrm{mmol}, 1.3$ equiv) was added via syringe, and the resulting mixture was heated to reflux. After stirring at reflux for $4 \mathrm{~h}$, analysis of the reaction mixture by thin-layer chromatography showed that complete conversion of the starting material to the acyl amidine had occurred (80\% ethyl acetate-hexane, $\mathrm{R}_{f}=0.44$ and 0.38 for the primary amide and the acyl

\footnotetext{
${ }^{17}$ Sawamura, M.; Nakayama, Y.; Kato, T.; Ito, Y. J. Org. Chem. 1995, 60, 1727.
} 
amidine, respectively), and the mixture was allowed to cool to $23^{\circ} \mathrm{C}$. Morpholine ( $43 \mu \mathrm{L}, 0.49 \mathrm{mmol}, 2.5$ equiv) was added to the reaction mixture at this point followed 3 min later by a solution of zirconium chloride in acetonitrile $\left(0.7 \mathrm{M}, 140 \mu \mathrm{L}, 0.098 \mathrm{mmol}, 0.5\right.$ equiv). After stirring for $1 \mathrm{~h}$ at $23^{\circ} \mathrm{C}$, the reaction mixture was diluted with ether $(2 \mathrm{~mL})$, and the diluted solution was filtered through a pad of Celite. The Celite pad was washed with ether $(3 \times 3 \mathrm{~mL})$, the filtrates were combined, and the combined solution was washed with $0.2 \mathrm{~N}$ aqueous sulfuric acid solution $(10 \mathrm{~mL})$. The aqueous layer was separated and extracted with two 5-mL portions of ether. The ethereal layers were combined, and the combined layers were washed sequentially with saturated aqueous sodium bicarbonate solution $(5 \mathrm{~mL})$ and saturated aqueous sodium chloride solution $(10 \mathrm{~mL})$. After washing, the ethereal solution was dried over anhydrous magnesium sulfate, and the dried solution was concentrated. The residue was purified by flash column chromatography on silica gel (40\% ethyl acetate-hexane) to afford $56.7 \mathrm{mg}$ of $N^{\alpha}$-(tert-butoxycarbonyl)-L-phenylalanine- $N$ morpholinamide ${ }^{18}$ as a clear oil (87\%): ${ }^{1} \mathrm{H}$ NMR (500 MHz, $\left.\mathrm{CDCl}_{3}\right) \delta$ 7.29-7.18 (m, $\left.5 \mathrm{H}, \mathrm{Ar}-\mathrm{H}\right), 5.44$ (d, J $=8.8 \mathrm{~Hz}, 1 \mathrm{H}$, BocNHCH), 4.78 (dt, J = 8.8, $5.9 \mathrm{~Hz}, 1 \mathrm{H}, \mathrm{NHCHCO}), 2.84-3.03(\mathrm{~m}, 4 \mathrm{H}$, morpholine CH), 3.24-3.27 (m, 1 H, morpholine C-H), 3.38-3.58 (m, 5 H, morpholine C-H and $\left.\mathrm{CHCH}_{2} \mathrm{Ph}\right), 1.41$ (s, $9 \mathrm{H}$, $\left.\mathrm{CH}\left(\mathrm{CH}_{3}\right)_{3}\right)$.

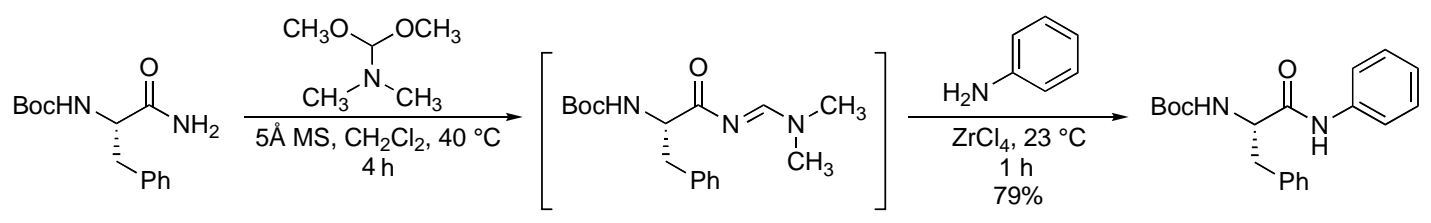

Transamidation of $N^{\alpha}$-(tert-Butoxycarbonyl)-L-phenylalaninamide with Aniline to form $N^{\alpha}$-(tertButoxycarbonyl)-L-phenylalanine- $N$-phenylamide using $N, N$-Dimethylformamide Dimethyl Acetal as Activator and Zirconium Chloride as Promoter. A 10-mL round-bottom flask containing a Tefloncoated stir bar and of crushed 5-A MS (225 mg) was evacuated ( $0.1 \mathrm{mmHg})$, and a good flame was applied for $\sim 2$ min to dry the sieves. The flame was removed, the flask was allowed to cool to $23^{\circ} \mathrm{C}$, and an argon atmosphere was introduced. $N^{\alpha}$-(tert-Butoxycarbonyl)-L-phenylalaninamide (55.2 mg, $0.208 \mathrm{mmol}$ ) and dichloromethane $(2.1 \mathrm{~mL})$ were added in sequence. After stirring for 5 min at $23{ }^{\circ} \mathrm{C}, \mathrm{N}, \mathrm{N}$ -

${ }^{18}$ (a) Katritzky, A. R.; He, H.-Y.; Jiang, R.; Long, Q. Tetrahedron: Asymmetry 2001, 12, 2427, Douat, C.; Heitz, A.; Martinez, J.; Fehrentz, J.-A. Tetrahedron Lett. 2000, 41, 37. 
dimethylformamide dimethyl acetal (DMF-DMA, $36.0 \mu \mathrm{L}, 0.271 \mathrm{mmol}, 1.3$ equiv) was added via syringe, and the resulting mixture was heated to reflux. After stirring at reflux for $4 \mathrm{~h}$, analysis of the reaction mixture by thin-layer chromatography showed that complete conversion of the starting material to the acyl amidine had occurred (80\% ethyl acetate-hexane, $\mathrm{R}_{f}=0.44$ and 0.38 for the primary amide and the acyl amidine, respectively), and the mixture was allowed to cool to $23^{\circ} \mathrm{C}$. Aniline (38 $\mu \mathrm{L}, 0.42 \mathrm{mmol}, 2.0$ equiv) was added to the reaction mixture at this point followed 3 min later by a solution of zirconium chloride in acetonitrile $\left(0.7 \mathrm{M}, 200 \mu \mathrm{L}, 0.141 \mathrm{mmol}, 0.5\right.$ equiv). After stirring for $1 \mathrm{~h}$ at $23^{\circ} \mathrm{C}$, the reaction mixture was diluted with ether $(2 \mathrm{~mL})$, and the diluted solution was filtered through a pad of Celite. The Celite pad was washed with ether $(3 \times 3 \mathrm{~mL})$, the filtrates were combined, and the combined solution was washed with $0.2 \mathrm{~N}$ aqueous sulfuric acid solution $(10 \mathrm{~mL})$. The aqueous layer was separated and extracted with two 5-mL portions of ether. The ethereal layers were combined, and the combined layers were washed sequentially with saturated aqueous sodium bicarbonate solution $(5 \mathrm{~mL})$ and saturated aqueous sodium chloride solution $(10 \mathrm{~mL})$. After washing, the ethereal solution was dried over anhydrous magnesium sulfate, and the dried solution was concentrated. The residue was purified by flash column chromatography on silica gel (30\% ethyl acetate-hexane) to afford $56.0 \mathrm{mg}$ of $N^{\alpha}$-(tert-butoxycarbonyl)-L-phenylalanine- $N$ phenylamide ${ }^{19}$ as a white solid (79\%): ${ }^{1} \mathrm{H}$ NMR $\left(500 \mathrm{MHz}, \mathrm{CDCl}_{3}\right) \delta 8.09$ (br s, CONHPh), 7.37-7.25 (m, 9 H, Ar-H), 7.14-7.06 (m, 1 H, Ar-H), 5.35 (br s, 1 H, BocNHCH), 4.56 (br s, 1 H, NHCHCO), 3.19-3.07 (m, $\left.2 \mathrm{H}, \mathrm{CHCH}_{2} \mathrm{Ph}\right), 1.41$ (s, $\left.9 \mathrm{H}, \mathrm{CH}\left(\mathrm{CH}_{3}\right)_{3}\right)$.

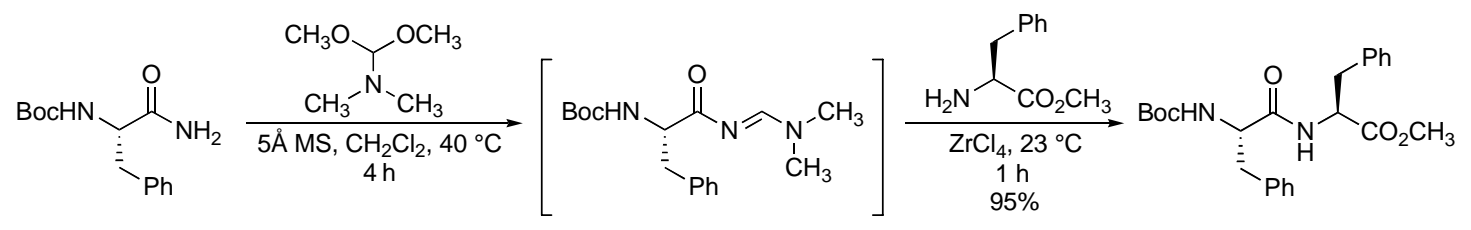

Transamidation of $N^{\alpha}$-(tert-Butoxycarbonyl)-L-phenylalaninamide with L-Phenylalanine Methyl Ester to form Boc-L-Phe-L-Phe-OMe using $N$, $N$-Dimethylformamide Dimethyl Acetal as Activator and Zirconium Chloride as Promoter. A 10-mL round-bottom flask containing a Teflon-coated stir bar and crushed 5-A MS (210 mg) was evacuated (0.1 mmHg), and a good flame was applied for 2 min to dry

\footnotetext{
${ }^{19}$ Obrecht, D.; Bohdal, U.; Broger, C.; Bur, D.; Lehmann, C.; Ruffieux, R.; Schönholzer, P.; Spiegler, C.; Müller, K. Helv. Chim. Acta 1995, 78, 563.
} 
the sieves. The flame was removed, the flask was allowed to cool to $23{ }^{\circ} \mathrm{C}$, and an argon atmosphere was introduced. $N^{\alpha}$-(tert-Butoxycarbonyl)-L-phenylalaninamide (50.0 $\mathrm{mg}, 0.189 \mathrm{mmol}$ ) and dichloromethane (1.9 mL) were added in sequence. After stirring for $5 \mathrm{~min}$ at $23{ }^{\circ} \mathrm{C}, N, N$-dimethylformamide dimethyl acetal (DMF-DMA, $33.0 \mu \mathrm{L}, 0.246 \mathrm{mmol}, 1.3$ equiv) was added via syringe, and the resulting mixture was heated to reflux. After stirring at reflux for $4 \mathrm{~h}$, analysis of the reaction mixture by thin-layer chromatography showed that complete conversion of the starting material to the acyl amidine had occurred ( $80 \%$ ethyl acetate-hexane, $\mathrm{R}_{f}=0.44$ and 0.38 for the primary amide and the acyl amidine, respectively), and the mixture was allowed to cool to $23^{\circ} \mathrm{C}$. L-Phenylalanine methyl ester (68 mg, $0.38 \mathrm{mmol}, 2.0$ equiv) was added to the reaction mixture at this point followed 3 min later by a solution of zirconium chloride in acetonitrile $\left(0.7 \mathrm{M}, 135 \mu \mathrm{L}, 0.095 \mathrm{mmol}, 0.5\right.$ equiv). After stirring for $1 \mathrm{~h}$ at $23^{\circ} \mathrm{C}$, the reaction mixture was diluted with ether ( $2 \mathrm{~mL})$, and the diluted solution was filtered through a pad of Celite. The Celite pad was washed with ether $(3 \times 3 \mathrm{~mL})$, the filtrates were combined, and the combined solution was washed with $0.2 \mathrm{~N}$ aqueous sulfuric acid solution $(10 \mathrm{~mL})$. The aqueous layer was separated and extracted with two 5-mL portions of ether. The ethereal layers were combined, and the combined layers were washed sequentially with saturated aqueous sodium bicarbonate solution (5 mL) and saturated aqueous sodium chloride solution $(10 \mathrm{~mL})$. After washing, the ethereal solution was dried over anhydrous magnesium sulfate, and the dried solution was concentrated. The residue was purified by flash column chromatography on silica gel (30\% ethyl acetate-hexane) to afford $76.6 \mathrm{mg}$ of Boc-L-Phe-L-Phe-OMe ${ }^{20}$ as a white solid (95\%): ${ }^{1} \mathrm{H}$ NMR (400 MHz, $\mathrm{CDCl}_{3}$ ) $\delta$ 7.30-7.18 (m, $\left.8 \mathrm{H}, \mathrm{Ar}-\mathbf{H}\right), 6.99$ (m, $\left.2 \mathrm{H}, \mathrm{Ar}-\mathbf{H}\right), 6.30$ (d, J = $7.0 \mathrm{~Hz}, 1$ H, CONHC), 4.95 (s, 1 H, BocNHC), 4.78 (app d, J = 6.6 Hz, 1 H, NHCHCO), 4.34-4.33 (m, 1 H,

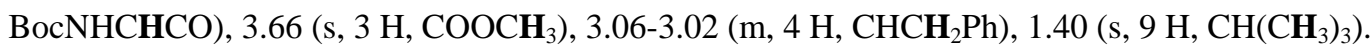

\footnotetext{
${ }^{20}$ Rzepecki, P.; Gallmeier, H.; Geib, N.; Cernovska, K.; König, B.; Schrader, T. J. Org. Chem. 2004, 69, 5168.
} 